\title{
Drivers of atmospheric methane uptake by montane forest soils in the southern Peruvian Andes
}

\author{
Sam P. Jones ${ }^{1, *}$, Torsten Diem ${ }^{2, *}$, Lidia P. Huaraca Quispe ${ }^{3}$, Adan J. Cahuana ${ }^{3}$, Dave S. Reay ${ }^{1}$, Patrick Meir ${ }^{4}$, and \\ Yit Arn Teh ${ }^{2}$ \\ ${ }^{1}$ School of Geosciences, University of Edinburgh, Edinburgh, UK \\ ${ }^{2}$ Institute of Biological and Environmental Sciences, University of Aberdeen, Aberdeen, UK \\ ${ }^{3}$ Universidad Nacional de San Antonio Abad del Cusco, Cusco, Peru \\ ${ }^{4}$ Research School of Biology, Australian National University, Canberra, Australia \\ *These authors contributed equally to this work.
}

Correspondence to: Sam P. Jones (sjones@bordeaux.inra.fr)

Received: 13 January 2016 - Published in Biogeosciences Discuss.: 27 January 2016

Revised: 25 May 2016 - Accepted: 25 May 2016 - Published: 21 July 2016

\begin{abstract}
The soils of tropical montane forests can act as sources or sinks of atmospheric methane $\left(\mathrm{CH}_{4}\right)$. Understanding this activity is important in regional atmospheric $\mathrm{CH}_{4}$ budgets given that these ecosystems account for substantial portions of the landscape in mountainous areas like the Andes. We investigated the drivers of net $\mathrm{CH}_{4}$ fluxes from premontane, lower and upper montane forests, experiencing a seasonal climate, in south-eastern Peru. Between February 2011 and June 2013, these soils all functioned as net sinks for atmospheric $\mathrm{CH}_{4}$. Mean (standard error) net $\mathrm{CH}_{4}$ fluxes for the dry and wet season were $-1.6(0.1)$ and $-1.1(0.1) \mathrm{mg} \mathrm{CH}_{4}-\mathrm{Cm}^{-2} \mathrm{~d}^{-1}$ in the upper montane forest, $-1.1(0.1)$ and $-1.0(0.1) \mathrm{mg} \mathrm{CH}_{4}-\mathrm{C} \mathrm{m}^{-2} \mathrm{~d}^{-1}$ in the lower montane forest, and $-0.2(0.1)$ and $-0.1(0.1) \mathrm{mg} \mathrm{CH}_{4}$ $\mathrm{C} \mathrm{m}^{-2} \mathrm{~d}^{-1}$ in the premontane forest. Seasonality in $\mathrm{CH}_{4}$ exchange varied among forest types with increased dry season $\mathrm{CH}_{4}$ uptake only apparent in the upper montane forest. Variation across these forests was best explained by available nitrate and water-filled pore space indicating that nitrate inhibition of oxidation or diffusional constraints imposed by changes in water-filled pore space on methanotrophic communities may represent important controls on soil-atmosphere $\mathrm{CH}_{4}$ exchange. $\mathrm{Net} \mathrm{CH}_{4}$ flux was inversely related to elevation; a pattern that differs to that observed in Ecuador, the only other extant study site of soil-atmosphere $\mathrm{CH}_{4}$ exchange in the tropical Andes. This may result from differences in rainfall patterns between the regions, suggesting that attention should be paid to the role of rainfall and
\end{abstract}

soil moisture dynamics in modulating $\mathrm{CH}_{4}$ uptake by the organic-rich soils typical of high-elevation tropical forests.

\section{Introduction}

Methane $\left(\mathrm{CH}_{4}\right)$ is an important greenhouse gas, accounting for at least a fifth of the climate forcing associated with increases in the atmospheric concentration of well-mixed greenhouse gases since the industrial revolution (Cicerone and Oremland, 1988; Myhre et al., 2013). Despite the importance of tropical landscapes in the global $\mathrm{CH}_{4}$ budget, the comparison of satellite retrievals of the atmospheric concentration of $\mathrm{CH}_{4}$ with source-sink inventories and bottomup process-based models indicates that these landscapes are poorly characterized (Bergamaschi et al., 2009; Bloom et al., 2010; Frankenberg et al., 2005). This likely reflects a historic imbalance in field observations when compared to the Northern Hemisphere. Soils play a key role in controlling atmospheric $\mathrm{CH}_{4}$ concentrations with emissions from inundated tropical wetland soils representing the largest natural source of atmospheric $\mathrm{CH}_{4}$, whilst well-drained soils represent the largest biological sink (Ciais et al., 2013). As soils are capable of acting as both globally significant sources or sinks for atmospheric $\mathrm{CH}_{4}$ they are of particular interest in refining our understanding of $\mathrm{CH}_{4}$ exchange across tropical landscapes (Dutaur and Verchot, 2007; Spahni et al., 2011). 
The function of a soil as source or sink for atmospheric $\mathrm{CH}_{4}$ is the net result of consumption and production by aerobic methanotrophic bacteria and anaerobic methanogenic archaea (Conrad, 1996; Le Mer and Roger, 2001). Welldrained soils are typically thought to act as net sinks for atmospheric $\mathrm{CH}_{4}$ because aerated soils support communities of high-affinity methanotrophic bacteria that oxidize $\mathrm{CH}_{4}$ at near-ambient concentrations (Bender and Conrad, 1992). In such soils, variations in the net flux of $\mathrm{CH}_{4}$ between soil and atmosphere are expected to be strongly influenced by constraints on the diffusional supply of $\mathrm{CH}_{4}$ to methanotrophs imposed by the structure of the soil pore network and the difference between gaseous- and aqueous-phase mass transfer of $\mathrm{CH}_{4}$ (Bender and Conrad, 1992; Conrad, 1996; Smith et al., 2003). This reliance on diffusion indicates that highaffinity methanotrophs are likely to occupy well-connected pore spaces, and as such uptake of atmospheric $\mathrm{CH}_{4}$ is also sensitive to water limitation under drier conditions (von Fischer et al., 2009). Additionally, methanotrophic activity may be inhibited by the presence of inorganic nitrogen; for example, through competition between $\mathrm{CH}_{4}$ and ammonium $\left(\mathrm{NH}_{4}^{+}\right)$for the active sites of the enzyme facilitating oxidation (Reay and Nedwell, 2004; Steudler et al., 1989). However, well-drained soils may also support anaerobic processes, concurrent with oxic conditions in the bulk soil matrix, within anoxic microsites (Conrad, 1996; Sexstone et al., 1985; Teh et al., 2005). These anoxic zones form as a result of physical limitations on the rate of oxygen $\left(\mathrm{O}_{2}\right)$ diffusion imposed by aggregate structure or saturation of soil pores both of which may promote the development of radial $\mathrm{O}_{2}$ gradients around occluded microsites (Burgin et al., 2011; Sexstone et al., 1985). Where biological $\mathrm{O}_{2}$ demand outstrips diffusional supply, these gradients can result in localized anoxia within such microsites (Burgin et al., 2011; Verchot et al., 2000). Under wet conditions and high $\mathrm{O}_{2}$ demand, anaerobic metabolic activity can be significant and potentially lead to $\mathrm{CH}_{4}$ emissions (Silver et al., 1999; Teh et al., 2005; Verchot et al., 2000). In these environments, methanotrophy can consume the majority of $\mathrm{CH}_{4}$ produced in situ through the activity of low affinity communities utilizing elevated $\mathrm{CH}_{4}$ concentrations at the interface of anoxic and oxic zones (Conrad, 1996; Teh et al., 2005). Consequently, variations in net flux may be expected to result from changes in relative size and connectivity of anoxic versus oxic zones (Silver et al., 1999; Teh et al., 2005) or from competition for substrates among methanogens and other anaerobes using more energetically favourable metabolic pathways such as the reduction of nitrate $\left(\mathrm{NO}_{3}^{-}\right.$; Chidthaisong and Conrad, 2000; von Fischer and Hedin, 2007; Teh et al., 2008).

Well-drained tropical soils are estimated to account for approximately a third of the global atmospheric soil sink for $\mathrm{CH}_{4}$ with nearly three-quarters of this uptake occurring within forest environments (Dutaur and Verchot, 2007). In Central and South America tropical forests are expansive, covering $\sim 35 \%$ of the South American continent (Eva et al.,
2004), and exhibit considerable spatial and temporal variability in soil-atmosphere $\mathrm{CH}_{4}$ exchange (Davidson et al., 2004; Keller et al., 1986, 2005; Steudler et al., 1996; Verchot et al., 2000). The majority of studies in the region have focussed on lowland forests below $600 \mathrm{~m}$ above sea level (a.s.l.). Variations in the strength of the soils of these forests as a sink for atmospheric $\mathrm{CH}_{4}$ are typically explained by the influence of soil texture and moisture on diffusion of $\mathrm{CH}_{4}$ belowground (Dutaur and Verchot, 2007; Kiese et al., 2008; Veldkamp et al., 2013; Verchot et al., 2000). However, $\mathrm{CH}_{4}$ emissions have been linked to the development of anoxic microsites in soils due to high levels of aerobic respiration, combined with periods of high water content (Verchot et al., 2000). Tropical montane forests are an extensive component of the tropical forest of South America, accounting for $\sim 8 \%$ of continental (Eva et al., 2004) and $\sim 25 \%$ of Andean landcover (Tovar et al., 2013), and yet they are under-represented in $\mathrm{CH}_{4}$ budgets. Currently, observations in the tropical Americas have been limited to Ecuador (Wolf et al., 2012), Brazil (Sousa Neto et al., 2011), Puerto Rico (Silver et al., 1999; Teh et al., 2005) and Panama (Veldkamp et al., 2013), making it difficult to predict the role of these environments in the regional $\mathrm{CH}_{4}$ cycle.

Moreover, it is possible that controls on $\mathrm{CH}_{4}$ flux from tropical montane forests may differ from their lowland forest counterparts. While the majority of tropical montane forest soils act as net sinks for atmospheric $\mathrm{CH}_{4}$ (Ishizuka et al., 2005b; Kiese et al., 2008; Purbopuspito et al., 2006; Sousa Neto et al., 2011; Veldkamp et al., 2013; Werner et al., 2006, 2007; Wolf et al., 2012), some ecosystems function as net atmospheric sources or fluctuate between source and sink activity (Delmas et al., 1992; von Fischer and Hedin, 2007; Schuur et al., 2001; Silver et al., 1999; Teh et al., 2005). Differences in behaviour among these environments may be partially explained by differences in underlying soil properties. The upper soil horizons of tropical montane forests typically accumulate more organic material than their lowland counterparts, leading to significant differences in the availability of labile carbon and nitrogen, and the evolution of very different soil structures (Nottingham et al., 2012; Teh et al., 2005; Zimmermann et al., 2009a). Similar contrasts exist between tropical montane forests where thick organic horizons develop (Purbopuspito et al., 2006; Wolf et al., 2012; Zimmermann et al., 2009a) and those where the superficial soils are organo-mineral in origin (Dubinsky et al., 2010; Silver et al., 1999). For example, in Ecuador net $\mathrm{CH}_{4}$ uptake across a tropical montane forest altitudinal transect was better predicted by carbon dioxide $\left(\mathrm{CO}_{2}\right)$ flux, $\mathrm{NH}_{4}^{+}$concentration and $\mathrm{pH}$, than soil moisture and texture (Wolf et al., 2012). Likewise, in analogous studies in Indonesia (Purbopuspito et al., 2006), Brazil (Sousa Neto et al., 2011) and northern Australia (Kiese et al., 2008), variations in soil moisture content over time had little or no effect on $\mathrm{CH}_{4}$ uptake. This is significant given that soil moisture and texture are typically strong predictors of net $\mathrm{CH}_{4}$ uptake in lowland ecosystems (Ver- 
chot et al., 2000) and play an important role in mechanistic models of soil $\mathrm{CH}_{4}$ uptake (Curry, 2007). In this context, evidence of nitrogen limitation of $\mathrm{CH}_{4}$ uptake in both lowland and montane tropical forests (Hassler et al., 2015; Veldkamp et al., 2013; Wolf et al., 2012) or evidence that $\mathrm{CH}_{4}$ production, driven by variations in soil $\mathrm{O}_{2}$ concentration, can play a significant role in the $\mathrm{CH}_{4}$ cycle of some tropical montane forests may help to explain these discrepancies (von Fischer and Hedin, 2007; Silver et al., 1999; Teh et al., 2005).

Here we present a study of soil-atmosphere $\mathrm{CH}_{4}$ exchange, for the period February 2011 to June 2013, from Andean upper montane, lower montane and premontane forests in south-eastern Peru that experience seasonal precipitation. A preliminary short-term dataset indicated that these forests act as a seasonably variable sink for atmospheric $\mathrm{CH}_{4}$ and that differences in net $\mathrm{CH}_{4}$ flux across the transition from forest to high-altitude grassland is driven by decreases in soil $\mathrm{O}_{2}$ concentration (Teh et al., 2014). We aim to (1) provide an assessment of variations in soil-atmosphere $\mathrm{CH}_{4}$ exchange among and within forest types across this landscape, based on a longer time series; and (2) investigate the drivers of $\mathrm{CH}_{4}$ flux across and within the forests of this landscape.

\section{Materials and methods}

\subsection{Study plots}

Nine plots were established along the Andes Biodiversity and Ecosystems Research Group altitudinal transect (Malhi et al., 2010; Teh et al., 2014) to study $\mathrm{CH}_{4}$ exchange in montane and premontane forests typical of the eastern flank of the Andes. In this region premontane forest extends from 600 to $1200 \mathrm{~m}$ a.s.l., lower montane cloud forest from 1200 to $2200 \mathrm{~m}$ a.s.1. and upper montane cloud forest from $2200 \mathrm{~m}$ a.s.1. to the tree line at $3400 \mathrm{~m}$ a.s.1. (Clark et al., 2014; Zimmermann et al., 2010a). Three montane forest plots were established between 2811 and $2962 \mathrm{~m}$ a.s.1., three lower montane forest plots between 1532 and $1786 \mathrm{~m}$ a.s.l. and three premontane forest plots between 1070 and $1088 \mathrm{~m}$ a.s.1. Plot characteristics are summarized in Table 1 .

The regional climate is seasonal with decreased rainfall and slightly lower temperatures during the dry season between May and September, with this pattern becoming more pronounced at higher elevation (Fig. 1). Rainfall and temperature are greater at lower elevations with total annual precipitations of 1700 and $2600 \mathrm{~mm}$ and mean annual air temperatures of 12.5 and $18.8^{\circ} \mathrm{C}$ at $\sim 3000$ and $1500 \mathrm{~m}$ a.s.l., respectively (Girardin et al., 2010). Total annual precipitation and mean annual air temperature at $\sim 1000 \mathrm{~m}$ a.s.l. are $5300 \mathrm{~mm}$ and $24.4{ }^{\circ} \mathrm{C}$.

The soils of these forests vary with elevation, most notably the surface soils in the montane forests typically consist of thick organic horizons, $\sim 20 \mathrm{~cm}$ deep in the upper and $\sim 10 \mathrm{~cm}$ deep in the lower, whilst those of the premontane forest are principally mineral in origin (Girardin et al., 2010; Zimmermann et al., 2009a). This pattern is reflected in the carbon contents of these soils with typical values for the superficial $10 \mathrm{~cm}$ in the upper and lower montane forests of 4050 and $<5 \%$ in the premontane forest (Zimmermann et al., 2009a). These soils are acidic with $\mathrm{pH}$ in the range of $\sim 4$.

Soil-atmosphere $\mathrm{CH}_{4}$ exchange for 2011 has previously been reported for these plots as part of a study investigating non- $\mathrm{CO}_{2}$ trace gas fluxes along an Andean altitudinal transect (Teh et al., 2014). These measurements indicated that the $\mathrm{CH}_{4}$ fluxes in the forests are small in comparison to source activity associated with wetlands in the montane grasslands found above the tree-line, with differences in $\mathrm{CH}_{4}$ flux across this gradient best explained by a non-linear inverse relationship with $\mathrm{O}_{2}$ concentration. In this analysis, the montane forests acted as sinks for atmospheric $\mathrm{CH}_{4}$ and the premontane forest had the potential to act as both a source or sink.

\subsection{Sampling strategy}

Each plot was 20 by $20 \mathrm{~m}$ and established approximately 3 months prior to the start of reported measurements in an attempt to minimize the effect of disturbances involved with installing sampling equipment (Varner et al., 2003). The premontane forest plots were situated on a ridge, slope and flat at 1070, 1070 and $1088 \mathrm{~m}$ a.s.1., respectively. Similarly, the lower montane forest plots were established on a ridge, slope and flat at 1768, 1532 and 1532 ma.s.l., respectively. Two of the upper montane forest plots were situated on slopes at 2811 and $2962 \mathrm{~m}$ a.s.1. and the third on a ridge at $2962 \mathrm{~m}$ a.s.1. The plots all broadly fall along the same lowland to highland transition, however, they were treated as independent measurements as spatial auto-correlation of $\mathrm{CH}_{4}$ exchange in tropical forests is small and the plots were more than $100 \mathrm{~m}$ apart (Ishizuka et al., 2005a; Purbopuspito et al., 2006).

Within each plot five soil collars were installed to allow for measurements of soil-atmosphere gas exchange using a static flux chamber method. Additionally, soil-gas equilibration chambers were buried at $10 \mathrm{~cm}$ adjacent to three collars in each plot to allow measurement of soil $\mathrm{O}_{2}$ concentrations. From September 2011 onwards, five ion exchange resin bags were buried in the upper $10 \mathrm{~cm}$ of each plot, adjacent to soil collars, to allow measurement of available inorganic $\mathrm{NH}_{4}^{+}$ and nitrate $\mathrm{NO}_{3}^{-}$.

Plots were visited monthly to measure soil-atmosphere gas exchange at each collar, and soil moisture and temperature adjacent to each collar, together with soil $\mathrm{O}_{2}$ concentration in each soil-gas equilibration chamber. Resin bags were also collected and replaced with new bags during these visits. These data were aggregated to produce monthly plot means of the measured variables. In the upper and lower montane forests, measurements ran from February 2011 to June 2013. In the premontane forest measurements ran from July 2011 
Table 1. Study area and plot characteristics.

\begin{tabular}{|c|c|c|c|c|c|c|c|c|c|c|}
\hline \multicolumn{6}{|c|}{ Study area } & \multicolumn{5}{|c|}{ Study plots } \\
\hline Field station & Forest type & $\begin{array}{l}\text { Longitude } \\
\left({ }^{\circ} \mathrm{S}\right)\end{array}$ & $\begin{array}{l}\text { Latitude } \\
\left({ }^{\circ} \mathrm{W}\right)\end{array}$ & $\begin{array}{r}\mathrm{MAT}^{\mathrm{a}} \\
\left({ }^{\circ} \mathrm{C}\right)\end{array}$ & $\begin{array}{r}\mathrm{MAP}^{\mathrm{a}} \\
(\mathrm{mm})\end{array}$ & $\begin{array}{l}\text { Elevation } \\
\text { (m a.s.l.) }\end{array}$ & Topography & $\begin{array}{l}\text { Bulk density } \\
\left(\mathrm{g} \mathrm{cm}^{-3}\right)\end{array}$ & $\begin{array}{l}\text { Particle density } \\
\qquad\left(\mathrm{g} \mathrm{cm}^{-3}\right)\end{array}$ & Porosity ${ }^{b}$ \\
\hline Villa Carmen & Pre-montane & $12^{\circ} 53^{\prime} 43^{\prime \prime}$ & $71^{\circ} 24^{\prime} 04^{\prime \prime}$ & 23.4 & 5300 & 1070 to 1088 & ridge, slope \& flat & 0.27 to 0.31 & 2.2 & 0.86 to 0.88 \\
\hline San Pedro & Lower montane & $13^{\circ} 02^{\prime} 56^{\prime \prime}$ & $71^{\circ} 32^{\prime} 13^{\prime \prime}$ & 18.8 & 2600 & 1532 to 1768 & ridge, slope \& flat & 0.09 to 0.22 & 1.7 & 0.87 to 0.95 \\
\hline Wayqecha & Upper montane & $13^{\circ} 11^{\prime} 24^{\prime \prime}$ & $71^{\circ} 35^{\prime} 13^{\prime \prime}$ & 12.5 & 1700 & 2811 to 2962 & ridge \& slopes & 0.08 to 0.11 & 1.4 & 0.92 to 0.94 \\
\hline
\end{tabular}

${ }^{\mathrm{a}}$ Mean annual air temperature and mean annual precipitation; ${ }^{\mathrm{b}}$ soil properties in the upper $10 \mathrm{~cm}$.

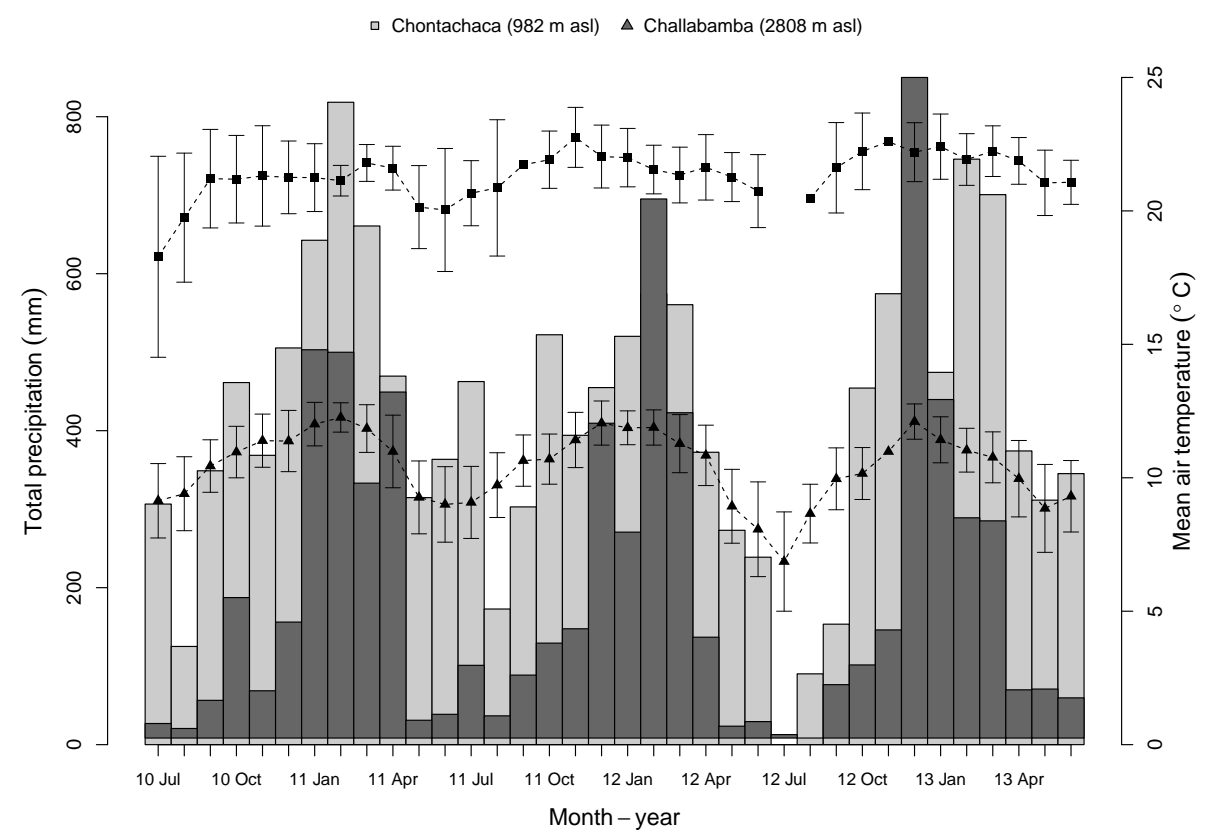

Figure 1. Total monthly precipitation and monthly mean diurnal temperature between July 2010 and June 2013 at $982 \mathrm{~m}$ a.s.1. (Chontachaca weather station: $13^{\circ} 01^{\prime} 26^{\prime \prime} \mathrm{S} 71^{\circ} 28^{\prime} 04^{\prime \prime} \mathrm{W}$ ) and $2808 \mathrm{~m}$ a.s.l. (Challabamba weather station: $13^{\circ} 13^{\prime} 03^{\prime \prime} \mathrm{S} 71^{\circ} 38^{\prime} 50^{\prime \prime} \mathrm{W}$ ). Temperature error bars are standard errors. No data were available for July 2012 at Contachaca. Plotted data were retrieved from the Servicio Nacional De Meteorogia e Hidrologia Del Peru (http://www.senamhi.gob.pe).

to June 2013. No data are available for these plots in October or December of 2011 and February, July or December of 2012 as high river levels prevented access.

\subsection{Soil-atmosphere gas exchange}

Net soil-atmosphere fluxes of $\mathrm{CH}_{4}$ and $\mathrm{CO}_{2}$ were determined using a static chamber method (Livingston and Hutchinston, 1995). Measurements were initiated by gently sealing cylindrical caps, using a section of inner-tube, to preinstalled soil collars to create a chamber of $\sim 0.08 \mathrm{~m}^{3}$ over a soil surface area of $\sim 0.03 \mathrm{~m}^{2}$. Soil collars had a diameter of $20 \mathrm{~cm}$ and were inserted to a depth of $\sim 5 \mathrm{~cm}$. Each cap was equipped with a gas sampling port, a vent and a $9 \mathrm{~V}$ computer fan (Hutchinson and Mosier, 1981; Pumpanen et al., 2004). Using a stopcock and $60 \mathrm{~mL}$ gas tight syringe, $20 \mathrm{~mL}$ gas samples were taken from the chambers at four discrete time steps over a period of $\sim 30 \mathrm{~min}$. Additionally, air temperature and atmospheric pressure were measured using a type $\mathrm{K}$ thermocouple (Omega Engineering Ltd., UK) and a Garmin GPSmap 60CSx (Garmin Ltd., USA). Gas samples were stored in over-pressured, pre-evacuated $12 \mathrm{~mL} \mathrm{Ex}$ etainers (Labco Ltd., UK) and concentrations of $\mathrm{CH}_{4}$ and $\mathrm{CO}_{2}$ were determined by gas chromatography. Gas chromatography was conducted using a Thermo TRACE GC Ultra (Thermo Fisher Scientific Inc., USA) with a helium carrier gas at the University of St Andrews. A flame ionization detector (FID) and methanizer-FID were used to determine $\mathrm{CH}_{4}$ and $\mathrm{CO}_{2}$ concentrations, respectively. Analytes were separated using a Hayesep Q 100/200 column. The gas chromatograph was equipped with a $2 \mathrm{~mL}$ sample loop and oven temperature was $60^{\circ} \mathrm{C}$. Detector responses were calibrated using three certified gas standards (CK Gas Products Ltd., UK: $1.8,9.8$ and $99.5 \mathrm{ppmv}^{\mathrm{CH}_{4}}$ ) and instrumental precision was deemed acceptable when coefficient of variances $<5 \%$ was achieved. A custom-built auto-sampler (University of York, UK) was used to introduce gas samples directly into the sample loop. 
Fluxes, in $\mu \mathrm{L} \mathrm{L}^{-1} \mathrm{~m}^{-2} \mathrm{~s}^{-1}$, were calculated in $\mathrm{R}$ ( $\mathrm{R}$ Core Team, 2013) using the HMR package (Pedersen, 2012) for flux estimation with static chamber data. Following the criteria outlined by Pedersen et al. (2010), HMR or linear models were fitted to time series of concentration in chamber headspaces. Significance was determined at the $p<0.05$ level with emission and uptake indicated by positive and negative flux values, respectively. Non-significant fluxes were excluded from further analysis. Fluxes were converted from a concentration to amount basis reported in $\mathrm{mg} \mathrm{C} \mathrm{m}^{-2} \mathrm{~d}^{-1}$ of $\mathrm{CH}_{4}$ and $\mathrm{g} \mathrm{C} \mathrm{m}^{-2} \mathrm{~d}^{-1}$ of $\mathrm{CO}_{2}$, following the ideal gas law, using measurements of air temperature and ambient pressure.

\subsection{Soil environmental conditions}

Soil $\mathrm{O}_{2}$ concentration was measured from soil gas equilibration chambers buried at $10 \mathrm{~cm}$ below the soil surface (Hall et al., 2013; Liptzin et al., 2011; Silver et al., 1999; Teh et al., 2005). Soil $\mathrm{O}_{2}$ concentration was determined by withdrawing $40 \mathrm{~mL}$ of gas from a soil-gas equilibration chamber using a stopcock and gas-tight syringe. The sample was then passed through the flow-through head of an MO-200 $\mathrm{O}_{2}$ sensor (Apogee Instruments Inc., USA) into a second syringe. The $\mathrm{O}_{2}$ reading was recorded at a constant volume and the gas sample re-injected into the soil-gas equilibration chamber from the second syringe. Prior to measurements the $\mathrm{O}_{2}$ sensor was calibrated, as required, in the field with ambient air and the dead volumes of the sampling apparatus evacuated to minimize contamination of the soil gas sample by residual atmospheric air. Chambers had an internal volume of $50 \mathrm{~mL}$ and a surface area of $75 \mathrm{~cm}^{2}$. Each consisted of a length of gas-permeable silicone rubber tubing (AP202/60 - $35 \mathrm{~mm}$ inner diameter by $1.5 \mathrm{~mm}$ wall, Advanced Polymers Ltd, UK) sealed at both ends with butyl rubber bungs. A suitable length of silicone tubing was passed through a hole in one of the bungs and capped with a stopcock to allow sampling at the surface. Chambers were encased in plastic mesh to protect the membrane during installation. Typical of similar designs, soil-gas equilibration chambers were capable of equilibrating with the external atmosphere in less than 24 h (Holter, 1990; Jacinthe and Dick, 1996; Kammann et al., 2001).

Soil volumetric water content was determined from triplicate measurements in the upper $6 \mathrm{~cm}$ of soil using a ML2x ThetaProbe (Delta-T Ltd., UK). Water-filled pore space (WFPS) was calculated from these data using estimates of porosity in the upper $10 \mathrm{~cm}$ based on plot averaged bulk density and forest type averaged particle density measurements (Table 1). Plot bulk densities were determined from the weight of volumetric soil samples after oven drying at $105^{\circ} \mathrm{C}$ for $24 \mathrm{~h}$. Forest type particle density was determined from measurements of bulked plot samples using a $10 \mathrm{~mL}$ pyncometer (Klute et al., 1986). Soil temperature was determined from triplicate measurements at $5 \mathrm{~cm}$ using a type $\mathrm{K}$ thermocouple penetration probe (Omega Engineering Ltd., $\mathrm{UK})$.

Available inorganic $\mathrm{NH}_{4}^{+}$and nitrate $\mathrm{NO}_{3}^{-}$concentrations were determined from resin bags buried in the upper $10 \mathrm{~cm}$ of soil (Giblin et al., 1994; Templer et al., 2005). Each resin bag consisted of $5 \mathrm{~g}$ of ion exchange resin (Dowex Marathon MR-3, Sigma Aldrich, UK) encased in a lycra bag. Resin bags were collected and replaced with a new bag during each plot visit. Following Templer et al. (2005), inorganic nitrogen was extracted from collected resin bags using $2 \mathrm{~N} \mathrm{KCL}$ and its concentration determined colorimetrically using a Burkard SFA2 (Burkard Scientific Ltd., Uxbridge, UK) continuous flow analyser at the University of Aberdeen. Available inorganic $\mathrm{NH}_{4}^{+}$and $\mathrm{NO}_{3}^{-}$concentrations were normalized to the amount of resin from which they were extracted and their deployment period, and reported as $\mu \mathrm{g} \mathrm{N}_{4}^{+}-\mathrm{Ng}^{-1}$ resin $\mathrm{d}^{-1}$ and $\mu \mathrm{g} \mathrm{NO} \mathrm{NO}^{-}-\mathrm{Ng}^{-1}$ resin $\mathrm{d}^{-1}$.

\subsection{Statistical analyses}

Statistical analysis was conducted in $\mathrm{R}$ version 3.1.1 ( $\mathrm{R}$ Core Team, 2013). Linear mixed-effect models were used to test the influence of forest type and season on measured variables as the dataset is unbalanced, with fewer measurements in the premontane forest, and nested within sampling month across plots (Pinheiro and Bates, 2000). In this respect, random intercept linear mixed-effect models computed using the NLME package were used to test the effect of forest type and season on monthly plot means of net $\mathrm{CH}_{4}$ flux, $\mathrm{CO}_{2}$ flux, soil $\mathrm{O}_{2}$ concentration, WFPS, soil temperature, available $\mathrm{NH}_{4}^{+}$and available $\mathrm{NO}_{3}^{-}$with forest type and season as fixed effects and sampling month and year as a random effect (Pinheiro et al., 2014). Following model fits, multiple comparison of forest type and season with Tukey contrasts was conducted in the Multcomp package (Hothorn et al., 2008) for simultaneous inference in parametric models. Time series of monthly plot means for these variables are provided in Figs. S1 to S7 in the Supplement. Spatial and temporal relationships between measured variables were investigated using Pearson's correlation coefficient in the Hmisc package (Harrell et al., 2015). Spatial correlations were tested on dataset plot means whilst temporal correlations were tested on monthly forest type means calculated, in both cases, from monthly plot means. The validity of parametric tests was confirmed through visual inspection of residuals and as a result available $\mathrm{NH}_{4}^{+}$and available $\mathrm{NO}_{3}^{+}$were square root transformed in all reported statistical analyses to reduce heteroscedacity (Zuur et al., 2007). Statistical significance is reported at $p<0.05$ unless stated otherwise. 
Table 2. Forest type means and standard errors for aggregated dry (May-September) and wet (October-April) season months. Capital letters indicate significant differences $(p<0.05)$ among forest types within season and lower case letters indicate significant differences between season within forest types.

\begin{tabular}{|c|c|c|c|c|c|c|c|c|c|c|c|c|c|c|}
\hline \multirow[t]{2}{*}{ Forest type } & \multicolumn{2}{|c|}{$\begin{array}{c}\mathrm{Net} \mathrm{CH}_{4} \text { flux } \\
\left(\mathrm{mg} \mathrm{C} \mathrm{m}^{-2} \mathrm{~d}^{-1}\right)\end{array}$} & \multicolumn{2}{|c|}{$\begin{array}{l}\mathrm{Net} \mathrm{CO} \mathrm{CO}_{2} \text { flux } \\
\left(\mathrm{g} \mathrm{C} \mathrm{m}^{-2} \mathrm{~d}^{-1}\right) \\
\end{array}$} & \multicolumn{2}{|c|}{$\begin{array}{c}\mathrm{O}_{2} \text { concentration } \\
(\%)\end{array}$} & \multicolumn{2}{|c|}{$\begin{array}{l}\text { WFPS } \\
(\%)\end{array}$} & \multicolumn{2}{|c|}{$\begin{array}{c}\text { Soil temperature } \\
\left({ }^{\circ} \mathrm{C}\right)\end{array}$} & \multicolumn{2}{|c|}{$\begin{array}{c}\text { Available } \mathrm{NH}_{4}^{+} \\
\left(\mathrm{\mu g} \mathrm{N} \mathrm{g}^{-1} \text { res. } \mathrm{d}^{-1}\right)\end{array}$} & \multicolumn{2}{|c|}{$\begin{array}{c}\text { Available } \mathrm{NO}_{3}^{-} \\
\left(\mu \mathrm{g} \mathrm{N} \mathrm{g}^{-1} \text { res. } \mathrm{d}^{-1}\right)\end{array}$} \\
\hline & Dry & Wet & Dry & Wet & Dry & Wet & Dry & Wet & Dry & Wet & Dry & Wet & Dry & Wet \\
\hline Pre-montane & $0.2(0.1)^{\mathrm{A}}$ & $-0.1(0.1)^{\mathrm{A}}$ & $5.2(0.3)^{\mathrm{A}}$ & $5.1(0.3)^{\mathrm{A}}$ & $19.7(0.3)^{\mathrm{A}}$ & $19.8(0.3)^{\mathrm{A}}$ & $50.9(2.1)^{\mathrm{A}}$ & $53.3(1.9)^{\mathrm{A}}$ & $20.4(0.2)^{\mathrm{A}}$ & $20.7(0.2)^{\mathrm{A}}$ & $10.0(0.6)$ & $17.9(0.05)$ & $21.0(0.1)^{\mathrm{A}}$ & $21.2(0.1)^{\mathrm{A}}$ \\
\hline Lower & $-1.1(0.1)^{\mathrm{B}}$ & $-1.0(0.1)^{\mathrm{B}}$ & $4.3(0.3)^{\mathrm{AB}}$ & $4.1(0.3)^{\mathrm{A}}$ & $19.1(0.3)^{\mathrm{AB}}$ & $19.2(0.2)^{\mathrm{AB}}$ & $35.4(2.0)^{\mathrm{Ba}}$ & $44.8(1.7)^{\mathrm{Bb}}$ & $17.3(0.2)^{\mathrm{Ba}}$ & $18.0(0.1)^{\mathrm{Bb}}$ & $7.8(0.6)$ & $14.8(0.5)$ & $6.4(0.1)^{\mathrm{B}}$ & $9.6(0.1)^{\mathrm{B}}$ \\
\hline Upper montane & $-1.6(0.1)^{C}$ & $-1.1(0.1)^{\mathrm{B}}$ & $2.9(0.3)^{\mathrm{B}}$ & $4.0(0.3)^{\mathrm{A}}$ & $18.6(0.3)^{\mathrm{B}}$ & $18.9(0.2)^{\mathrm{B}}$ & $24.4(2.0)^{\mathrm{Ca}}$ & $43.7(1.7)^{\mathrm{Bb}}$ & $11.0(0.2)^{\mathrm{Ca}}$ & $11.9(0.1)^{\mathrm{Cb}}$ & $10.8(0.6)$ & $18.6(0.5)$ & $0.4(0.1)^{\mathrm{C}}$ & $1.1(0.0)^{\mathrm{C}}$ \\
\hline
\end{tabular}
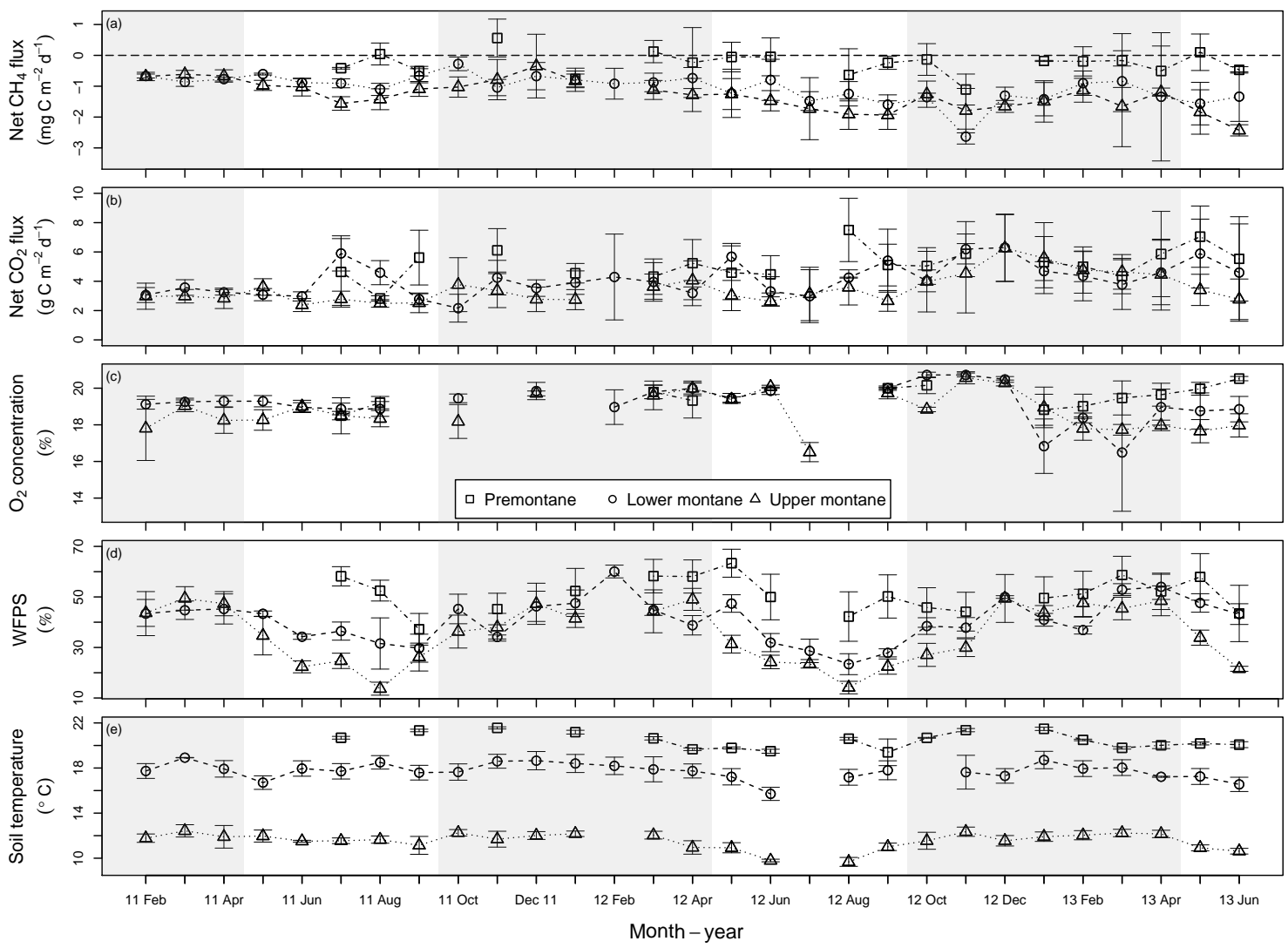

Figure 2. Monthly forest type means and standard deviation of (a) net $\mathrm{CH}_{4}$ flux, (b) net $\mathrm{CO}_{2}$ flux, (c) soil $\mathrm{O}_{2}$ concentration, (d) WFPS and (e) soil temperature. Shading indicates the wet season of October-April.

\section{Results}

\subsection{Variability in gas fluxes and soil environmental conditions}

Fluxes of $\mathrm{CH}_{4}$ were influenced by forest type with greater uptake at higher elevations (Table 2). All the forest types acted as a net sink for atmospheric $\mathrm{CH}_{4}$ with mean (standard error) net $\mathrm{CH}_{4}$ fluxes for dry and wet season of $-1.6(0.1)$ and $-1.1(0.1) \mathrm{mg} \mathrm{CH}_{4}-\mathrm{C} \mathrm{m}^{-2} \mathrm{~d}^{-1}$ in the upper montane forest, $-1.1(0.1)$ and $-1.0(0.1) \mathrm{mg} \mathrm{CH}_{4}-\mathrm{C} \mathrm{m}^{-2} \mathrm{~d}^{-1}$ in the lower montane forest and $-0.2(0.1)$ and $-0.1(0.1) \mathrm{mg} \mathrm{CH}_{4}$ $\mathrm{C} \mathrm{m}^{-2} \mathrm{~d}^{-1}$ in the premontane forest. During the dry season, net $\mathrm{CH}_{4}$ fluxes varied among all forest types. During the wet season, $\mathrm{CH}_{4}$ uptake was smaller in the premontane forest than in both the upper and lower montane forests. Within forest types, no differences were identified between the dry and wet seasons when data from all time points were aggregated together. However, monthly time series from the upper montane forest indicate seasonal variability of exchange, with a modest shift towards greater $\mathrm{CH}_{4}$ uptake with the progression of the dry season (Fig. 2a). Uptake dominated soilatmosphere exchange in the upper and lower montane forests with emissions accounting for only 1 and $2 \%$ of monthly mean $\mathrm{CH}_{4}$ fluxes, respectively. In contrast, whilst also a net sink for atmospheric $\mathrm{CH}_{4}$, emissions were more common in the premontane forest with $29 \%$ of fluxes registering net $\mathrm{CH}_{4}$ efflux. 
Fluxes of $\mathrm{CO}_{2}$ were influenced by forest type with larger fluxes at lower elevations (Table 2). Fluxes of $\mathrm{CO}_{2}$ for aggregated dry and wet season months were $2.9(0.3)$ and 4.0 (0.3) $\mathrm{g} \mathrm{CO}_{2}-\mathrm{C} \mathrm{m}^{-2} \mathrm{~d}^{-1}$ in the upper montane forest, $4.3(0.3)$ and $4.1(0.3) \mathrm{g} \mathrm{CO}_{2}-\mathrm{C} \mathrm{m}^{-2} \mathrm{~d}^{-1}$ in the lower montane forest and $5.2(0.3)$ and $5.1(0.3) \mathrm{g} \mathrm{CO}_{2}-\mathrm{C} \mathrm{m}^{-2} \mathrm{~d}^{-1}$ in the premontane forest (Fig. 2b). Dry-season $\mathrm{CO}_{2}$ fluxes were smaller in the upper montane forest than both the premontane forests, whilst during the wet season no differences were identified. Within forest types, there were no seasonal differences in $\mathrm{CO}_{2}$ flux but some evidence of wet season increases from the upper montane forest is apparent in the monthly time series (Fig. 2b).

Soil $\mathrm{O}_{2}$ concentration at $10 \mathrm{~cm}$ soil depth was influenced by forest type with slightly greater concentrations at lower elevation (Table 2). Soil $\mathrm{O}_{2}$ concentrations for aggregated dry and wet season months were $18.6(0.3)$ and $18.9(0.2) \%$ in the upper montane forest, $19.1(0.3)$ and $19.2(0.2) \%$ in the lower montane forest and $19.7(0.3)$ and $19.8(0.3) \%$ in the premontane forest (Fig. 2c). In both wet and dry season, soil $\mathrm{O}_{2}$ concentration was smaller in the upper montane than the premontane forest. However, these differences were marginal with a range of $1.1 \%$. Within forest types no differences in soil $\mathrm{O}_{2}$ concentration between seasons were identified and little temporal variability is apparent in the monthly time series (Fig. 2c).

WFPS was influenced by forest type and its interaction with season, with greater saturation at lower elevation and during the wet season (Table 2). Mean WFPS for aggregated dry and wet season months was 24.4 (2.0) and 43.7 (1.7) \% in the upper montane forest, 35.4 (2.0) and 44.8 (1.7) \% in the lower montane forest and 50.9 (2.1) and 53.3 (1.9) \% in the premontane forest. Dry season WFPS was different between all forest types. During the wet season WFPS in the premontane forest was greater than those from both the upper and lower montane forests. Within forest types, WFPS was greater for wet rather than for dry season for both the upper and lower montane forests as characterized by strong seasonality apparent in the monthly time series for these forests (Fig. 2d).

Soil temperature was influenced by forest type and its interaction with season, with greater temperatures at lower elevation and during the wet season (Table 2). Mean soil temperature for aggregated dry and wet season months was 11.0 (0.2) and $11.9(0.1)^{\circ} \mathrm{C}$ in the upper montane forest, $17.3(0.2)$ and $18.0(0.1)^{\circ} \mathrm{C}$ in the lower montane forest and $20.4(0.2)$ and $20.7(0.2)^{\circ} \mathrm{C}$ in the premontane forest (Fig. 2e). In both seasons, soil temperatures were different between all forest types. Within forest types, soil temperatures were greater during the wet than during the dry season in both the upper and lower montane forests (Fig. 2e).

Variation in the availability of inorganic nitrogen differed between compounds (Fig. 3). Available $\mathrm{NH}_{4}^{+}$was not influenced by forest type or season (Table 2). Mean aggregated dry and wet season concentrations ranged from 7.8 to $10.8 \mu \mathrm{g} \mathrm{NH}_{4}^{+}-\mathrm{Ng}^{-1}$ resin $\mathrm{d}^{-1}$ and 14.8 to $18.6 \mu \mathrm{g} \mathrm{NH}_{4}^{+}-$ $\mathrm{Ng}^{-1}$ resin $\mathrm{d}^{-1}$, respectively. In contrast, available $\mathrm{NO}_{3}^{-}$was influenced by forest type with greater availability at lower elevations (Table 2). Mean available $\mathrm{NO}_{3}^{-}$for aggregated dry and wet season months was $0.4(0.1)$ and $1.1(0.0) \mu \mathrm{g} \mathrm{NO}_{3}^{-}$ $\mathrm{Ng}^{-1}$ resin $\mathrm{d}^{-1}$ in the upper montane forest, $6.4(0.1)$ and $9.6(0.1) 21.0(0.1) \mu \mathrm{g} \mathrm{NO}_{3}^{-}-\mathrm{Ng}^{-1}$ resin $\mathrm{d}^{-1}$ in the lower montane forest and $21.0(0.1)$ and $21.2(0.1) \mu \mathrm{g} \mathrm{NO}_{3}^{-}$$\mathrm{Ng}^{-1}$ resin $\mathrm{d}^{-1}$ in the premontane forest. Available $\mathrm{NO}_{3}^{-}$ was different between all forest types with no seasonal differences, in part due to considerable within plot variability and within forest type.

\subsection{Spatial relationships between gas fluxes and environmental conditions}

Across these forests, plot means of net $\mathrm{CH}_{4}$ flux were negatively correlated with elevation (Pearson's $r=-0.81$, $p<0.01, n=9$ ), soil porosity (Pearson's $r=-0.72$, $p=0.03, n=9$ ) and plot means of $\mathrm{CO}_{2}$ flux (Pearson's $r=-0.61, p=0.08, n=9$ (Table 3). Plot means of net $\mathrm{CH}_{4}$ flux were positively correlated with the plot means of WFPS (Pearson's $r=0.84, \quad p<0.01, n=9$ ), soil temperature (Pearson's $r=0.83, p<0.01, n=9$ ) and soil $\mathrm{O}_{2}$ concentration (Pearson's $r=0.73, p=0.03, n=9$ ), available $\mathrm{NH}_{4}^{+}$(Pearson's $r=0.71, p=0.03, n=9$ ) and available $\mathrm{NO}_{3}^{-}$(Pearson's $r=0.88, p=<0.01, n=9$ ), respectively. Notable co-correlations exist between the plot means of many measured environmental variables. For example, strong correlations (i.e. $p<0.01$ ) exist between plot means of net $\mathrm{CH}_{4}$ flux and elevation, WFPS, soil temperature and available $\mathrm{NO}_{3}^{-}$. However, both WFPS (Pearson's $r=-0.79$, $p=0.01, n=9$ ) and available $\mathrm{NO}_{3}^{-}$(Pearson's $r=-0.94$, $p<0.01, n=9$ ) are significantly negatively correlated with elevation and are also significantly positively correlated with each other (Pearson's $r=0.83, p<0.01, n=9$ ).

\subsection{Temporal relationships between gas fluxes and environmental conditions}

The drivers of temporal variability in net $\mathrm{CH}_{4}$ flux varied among forest types (Table 4). In the upper montane forest, monthly forest type mean net $\mathrm{CH}_{4}$ flux was positively correlated with WFPS (Pearson's $r=0.54, p<0.01, n=28$ ) and soil temperature (Pearson's $r=0.52, p<0.01, n=27$ ). Similar to spatial co-correlations observed across plots, monthly forest type means of WFPS and soil temperature (Pearson's $r=0.60, p<0.01, n=27$ ) were positively correlated with each other in the upper montane forest. In contrast, monthly forest type mean net $\mathrm{CH}_{4}$ flux was negatively correlated with $\mathrm{CO}_{2}$ flux (Pearson's $r=-0.70, p<0.01, n=29$ ) in the lower montane forest. Whilst in the premontane forest, no strong correlations between monthly forest type mean net $\mathrm{CH}_{4}$ flux and other measured variables were identified. Here the strongest relationship with net $\mathrm{CH}_{4}$ flux was a positive 
Table 3. Pearson's correlation coefficient matrix for dataset plot means of measured variables across forest types.

\begin{tabular}{lrrrrrrr}
\hline Variable pairs & $\begin{array}{r}\mathrm{Net}_{\mathrm{CH}_{4}} \\
\text { flux }\end{array}$ & $\begin{array}{r}\mathrm{Net} \mathrm{CO}_{2} \\
\text { flux }\end{array}$ & $\begin{array}{r}\mathrm{O}_{2} \\
\text { concentration }\end{array}$ & WFPS & $\begin{array}{r}\text { Soil } \\
\text { temperature }\end{array}$ & $\begin{array}{r}\sqrt{ } \text { Available } \\
\mathrm{NH}_{4}^{+}\end{array}$ & $\begin{array}{r}\sqrt{ } \text { Available } \\
\mathrm{NO}_{3}^{-}\end{array}$ \\
\hline Net $\mathrm{CO}_{2}$ flux & 0.61 & - & - & - & - & - & - \\
$\mathrm{O}_{2}$ concentration & $0.73^{*}$ & 0.55 & - & - & - & - & - \\
WFPS & $0.84^{* *}$ & 0.43 & 0.51 & - & - & - & - \\
Soil temperature & $0.83^{* *}$ & 0.66 & $0.77^{*}$ & $0.79^{*}$ & - & - & - \\
$\sqrt{ }$ Available $\mathrm{NH}_{4}^{+}$ & $0.71^{*}$ & 0.36 & 0.31 & 0.41 & 0.25 & - & - \\
$\sqrt{ }$ Available $\mathrm{NO}_{3}^{-}$ & $0.88^{* *}$ & $0.67^{*}$ & $0.72^{*}$ & $0.83^{* *}$ & $-0.94^{* *}$ & 0.42 & - \\
Elevation & $-0.81^{* *}$ & -0.66 & $-0.76^{*}$ & $-0.79^{*}$ & $-1.00^{* *}$ & -0.22 & $-0.94^{* *}$ \\
Porosity & $-0.72^{*}$ & $-0.75^{*}$ & -0.59 & $-0.68^{*}$ & $-0.80^{*}$ & -0.23 & $-0.86^{* *}$ \\
\hline
\end{tabular}

** $p<0.01,{ }^{*} p<0.05$

Table 4. Pearson's correlation coefficient matrix for monthly forest type means of measured variables within forest types.

\begin{tabular}{|c|c|c|c|c|c|c|c|}
\hline Forest type & Variable pairs & $\begin{array}{r}\text { Net } \mathrm{CH}_{4} \\
\text { flux }\end{array}$ & $\begin{array}{r}\text { Net } \mathrm{CO}_{2} \\
\text { flux }\end{array}$ & $\begin{array}{r}\mathrm{O}_{2} \\
\text { concentration }\end{array}$ & WFPS & $\begin{array}{r}\text { Soil } \\
\text { temperature }\end{array}$ & $\begin{array}{r}\sqrt{ } \text { Available } \\
\mathrm{NH}_{4}^{+}\end{array}$ \\
\hline \multirow[t]{6}{*}{ Premontane } & Net $\mathrm{CO}_{2}$ flux & -0.21 & - & - & - & - & - \\
\hline & $\mathrm{O}_{2}$ concentration & 0.05 & 0.33 & - & - & - & - \\
\hline & WFPS & 0.33 & -0.34 & -0.44 & - & - & - \\
\hline & Soil temperature & -0.16 & 0.13 & -0.44 & $-0.49^{*}$ & - & - \\
\hline & $\sqrt{ }$ Available $\mathrm{NH}_{4}^{+}$ & -0.05 & 0.00 & 0.47 & -0.38 & 0.11 & - \\
\hline & $\sqrt{ }$ Available $\mathrm{NO}_{3}^{-}$ & -0.25 & 0.20 & 0.46 & -0.46 & 0.03 & $0.93^{* *}$ \\
\hline \multirow[t]{6}{*}{ Lower montane } & Net $\mathrm{CO}_{2}$ flux & $-0.70^{* *}$ & - & - & - & - & - \\
\hline & $\mathrm{O}_{2}$ concentration & -0.20 & 0.08 & - & - & - & - \\
\hline & WFPS & 0.16 & 0.15 & -0.23 & - & - & - \\
\hline & Soil temperature & 0.08 & -0.08 & -0.29 & 0.12 & - & - \\
\hline & $\sqrt{ }$ Available $\mathrm{NH}_{4}^{+}$ & 0.04 & -0.20 & 0.37 & -0.11 & 0.40 & - \\
\hline & $\sqrt{ }$ Available $\mathrm{NO}_{3}^{-}$ & -0.14 & 0.06 & 0.53 & 0.22 & 0.35 & 0.24 \\
\hline \multirow[t]{6}{*}{ Upper montane } & Net $\mathrm{CO}_{2}$ flux & -0.20 & - & - & - & - & - \\
\hline & $\mathrm{O}_{2}$ concentration & 0.04 & 0.09 & - & - & - & - \\
\hline & WFPS & $0.54^{* *}$ & $0.49^{* *}$ & 0.09 & - & - & - \\
\hline & Soil temperature & $0.52^{* *}$ & 0.29 & -0.21 & $0.60^{* *}$ & - & - \\
\hline & $\sqrt{ }$ Available $\mathrm{NH}_{4}^{+}$ & 0.19 & 0.11 & 0.03 & -0.10 & 0.11 & - \\
\hline & $\sqrt{ }$ Available $\mathrm{NO}_{3}^{-}$ & -0.02 & 0.46 & -0.32 & $0.53^{*}$ & $0.54^{*}$ & 0.39 \\
\hline
\end{tabular}

${ }^{* *} p<0.01,{ }^{*} p<0.05$

correlation with monthly forest type mean WFPS (Pearson's $r=0.33, p=0.16, n=19)$.

\section{Discussion}

\subsection{Uptake of $\mathrm{CH}_{4}$ by Andean forest soils in southern Peru}

Upper montane, lower montane and premontane forests in the southern tropical Andes of Peru principally acted as sinks for atmospheric $\mathrm{CH}_{4}$ (Fig. 2a). Seasonal mean net $\mathrm{CH}_{4}$ fluxes from these soils ranged from -1.6 to $-0.1 \mathrm{mg} \mathrm{CH}_{4}$ $\mathrm{C} \mathrm{m}^{-2} \mathrm{~d}^{-1}$ (Table 2), indicating that soil-atmosphere $\mathrm{CH}_{4}$ exchange in these forests is comparable to those previously reported and in similar environments elsewhere. The major difference between the exchange rates reported here and the preliminary analysis of these data by Teh et al. (2014) is that the longer time series indicates that these premontane forests act as a net sink rather than source of atmospheric $\mathrm{CH}_{4}$ during the wet season. Reported mean net $\mathrm{CH}_{4}$ fluxes for tropical forest soils above $600 \mathrm{~m}$ a.s.l. range from -1.6 to $-0.2 \mathrm{mg} \mathrm{CH}_{4}-\mathrm{C} \mathrm{m}^{-2} \mathrm{~d}^{-1}$ for the northern Andes in Ecuador (Wolf et al., 2012), -0.9 to $-0.2 \mathrm{mg} \mathrm{CH}_{4}$ $\mathrm{C} \mathrm{m}^{-2} \mathrm{~d}^{-1}$ for central Sumatra and Sulawesi in Indonesia (Ishizuka et al., 2005b; Purbopuspito et al., 2006), -0.1 to $0.0 \mathrm{mg} \mathrm{CH}_{4}-\mathrm{C} \mathrm{m}^{-2} \mathrm{~d}^{-1}$ for Mayombe highlands in the Republic of Congo (Delmas et al., 1992), $-0.7 \mathrm{mg} \mathrm{CH}_{4}$ $\mathrm{C} \mathrm{m}^{-2} \mathrm{~d}^{-1}$ for a tableland in northern Australia (Kiese et 


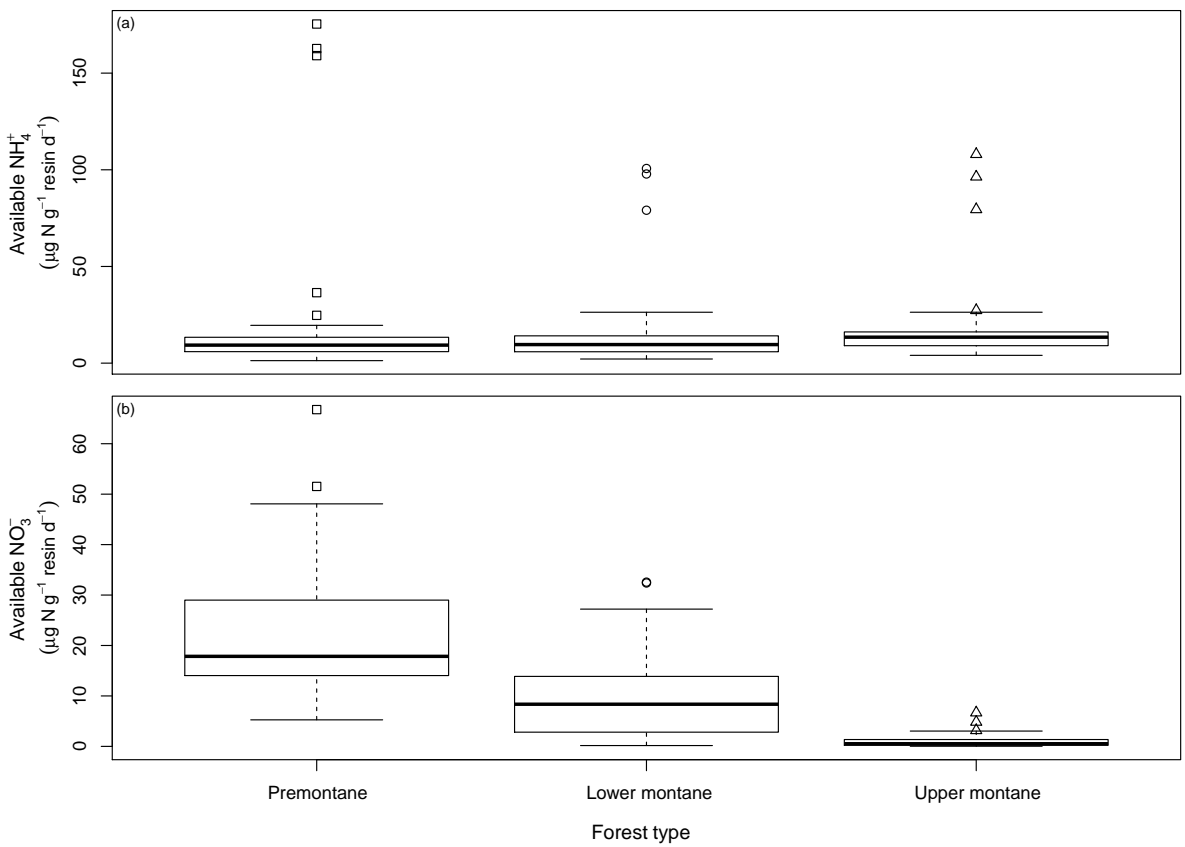

Figure 3. Boxplots of monthly plot means of inorganic nitrogen availability by forest type (a) available $\mathrm{NH}_{4}^{+}$and $(\mathbf{b})$ available $\mathrm{NO}_{3}^{-}$.

al., 2008), $-1.4 \mathrm{mg} \mathrm{CH}_{4}-\mathrm{Cm}^{-2} \mathrm{~d}^{-1}$ in Kenya (Werner et al., 2007), $-0.5 \mathrm{mg} \mathrm{CH}_{4}-\mathrm{C} \mathrm{m}^{-2} \mathrm{~d}^{-1}$ in China (Werner et al., 2006), $-0.1 \mathrm{mg} \mathrm{CH}_{4}-\mathrm{C} \mathrm{m}^{-2} \mathrm{~d}^{-1}$ in Panama (Veldkamp et al., 2013) and $-1.2 \mathrm{mg} \mathrm{CH}_{4}-\mathrm{C} \mathrm{m}^{-2} \mathrm{~d}^{-1}$ for Atlantic forest in Brazil (Sousa Neto et al., 2011). Similarly, mean soilatmosphere $\mathrm{CH}_{4}$ exchange rates for lowland tropical forests in South America have been reported in the range of -1.4 to $-0.1 \mathrm{mg} \mathrm{CH}_{4}-\mathrm{C} \mathrm{m}^{-2} \mathrm{~d}^{-1}$ (Davidson et al., 2008; Fernandes et al., 2002; Keller et al., 1986, 2005; Sousa Neto et al., 2011; Steudler et al., 1996; Verchot et al., 2000).

Within forest types, net $\mathrm{CH}_{4}$ fluxes were not significantly different between wet and dry season, indicating that these forests show little overall seasonal variability in net $\mathrm{CH}_{4}$ uptake (Table 2). However, the time series of net $\mathrm{CH}_{4}$ flux (Fig. 2a) for the upper montane forest does suggest that $\mathrm{CH}_{4}$ uptake increases with the procession of the dry season; ultimately equating to a $\sim 30 \%$ difference between dry and wet season. Our inability to detect a statistically significant difference between seasons (Table 2) may reflect interannual variability, and the fact that environmental conditions change gradually across seasonal transitions (Clark et al., 2014). The aseasonality of $\mathrm{CH}_{4}$ exchange in the lower montane and premontane forests conforms with observations from tropical montane forests in Ecuador and Indonesia with aseasonal climates (Purbopuspito et al., 2006; Wolf et al., 2012), while the behaviour of the upper montane forests appears more similar to that of lowland tropical forests with seasonal climates (Davidson et al., 2008; Keller et al., 2005; Verchot et al., 2000). This may in part reflect the fact that seasonal varia- tions in rainfall and temperature become more pronounced with elevation across this transect (Fig. 1).

We did not observe notable spatial or temporal hotspots of $\mathrm{CH}_{4}$ emission in these forests, contrasting with observations from regions such as the Caribbean and Hawaii (Schuur et al., 2001; Silver et al., 1999; Teh et al., 2005). For example, Silver et al. (1999) report mean net $\mathrm{CH}_{4}$ fluxes of 0.2 to $73.2 \mathrm{mg} \mathrm{CH}_{4}-\mathrm{C} \mathrm{m}^{-2} \mathrm{~d}^{-1}$ from montane ecosystems in Puerto Rico. Indeed, emissions represented only $1-2 \%$ of fluxes in the upper and lower montane forests of this study. Emissions were more prevalent in the premontane forest, accounting for $29 \%$ of fluxes, suggesting that emission hotspots are possible in these soils but may not have been captured by our sampling strategy (Delmas et al., 1992; Silver et al., 1999). Assessing and studying the potential for emissions from these ecosystems is likely to require higher resolution observations to capture spatial and temporal variability (Liptzin et al., 2011; Silver et al., 1999) combined with experimental manipulations (Hall et al., 2013) and a better understanding of below-ground $\mathrm{CH}_{4}$ cycling (von Fischer and Hedin, 2007; Teh et al., 2005).

\subsection{Environmental controls on net $\mathrm{CH}_{4}$ fluxes in tropical Andean forests of southern Peru}

The increase in $\mathrm{CH}_{4}$ uptake with elevation across the transect was strongly related to decreases in available $\mathrm{NO}_{3}^{-}$, WFPS and soil temperature (Fig. 4). As there is considerable covariance between these environmental conditions (Table 3) a number of plausible, but confounded, mechanisms may explain why $\mathrm{CH}_{4}$ uptake was greatest in the upper montane 
Table 5. Characteristics and annual mean net $\mathrm{CH}_{4}$ fluxes reported for montane forests in Peru (this study), Ecuador (Wolf et al., 2012) and Indonesia (Purbopuspito et al., 2006).

\begin{tabular}{llllrrr}
\hline Country & Forest type & $\begin{array}{l}\text { Elevation } \\
\text { (m a.s.1.) }\end{array}$ & $\begin{array}{l}\text { Organic horizon } \\
\text { thickness }(\mathrm{cm})\end{array}$ & $\begin{array}{r}\mathrm{MAT}^{\mathrm{a}} \\
\left({ }^{\circ} \mathrm{C}\right)\end{array}$ & $\begin{array}{r}\mathrm{MAP}^{\mathrm{a}} \\
(\mathrm{mm})\end{array}$ & $\begin{array}{r}\mathrm{Net} \mathrm{CH}_{4} \text { flux } \\
\left(\mathrm{mg} \mathrm{C} \mathrm{m}^{-2} \mathrm{~d}^{-1}\right)\end{array}$ \\
\hline \multirow{2}{*}{ Ecuador } & Premontane & 900 to 1200 & 2.5 to 6.5 & 19.4 & 2230 & -1.5 \\
& Lower montane & 1800 to 2100 & 4.0 to 24.0 & 15.7 & 1950 & -0.9 \\
& Upper montane & 2800 to 3000 & 6.6 to 22.2 & 9.4 & 4500 & -0.3 \\
\hline \multirow{2}{*}{ Peru } & Premontane & 1070 to 1088 & $<5$ & 23.4 & 5300 & -0.2 \\
& Lower montane & 1532 to 1768 & $\sim 10$ & 18.8 & 2600 & -1.1 \\
& Upper montane & 2811 to 2962 & $\sim 20$ & 12.5 & 1700 & -1.3 \\
\hline \multirow{2}{*}{ Indonesia } & Premontane & 1190 & 0 & 22.5 & 1500 & -0.7 \\
& Lower montane & 1800 & 15 to 25 & 18.3 & - & -0.9 \\
& Upper montane & 2470 & 10 to 20 & 14.6 & - & -0.4 \\
\hline
\end{tabular}

${ }^{\mathrm{a}}$ Mean annual air temperature and mean annual precipitation.

forest and smallest in the premontane forest. The predominance of $\mathrm{CH}_{4}$ uptake and the lack of evidence for widespread anoxia, with soil $\mathrm{O}_{2}$ measurements typically in excess of $15 \%$ (Fig. 2c), indicates that net $\mathrm{CH}_{4}$ exchange was dominated by the activity of high affinity methanotrophs which are unlikely to be sensitive to $\mathrm{O}_{2}$ availability (Bender and Conrad, 1992; Teh et al., 2006). Indeed, unlike studies where landscapes exhibiting net source activity are considered we did not find evidence that decreases in $\mathrm{O}_{2}$ concentration were driving $\mathrm{CH}_{4}$ exchange (Silver et al., 1999; Teh et al., 2014). The positive relationship between available $\mathrm{NO}_{3}^{+}$and net $\mathrm{CH}_{4}$ flux (Fig. 4b) may suggest that $\mathrm{CH}_{4}$ uptake was inhibited by $\mathrm{NO}_{3}^{-}$. This observation supports previous, albeit poorly understood, observations that $\mathrm{CH}_{4}$ oxidation is more sensitive to the presence of $\mathrm{NO}_{3}^{-}$rather than $\mathrm{NH}_{4}^{+}$ (Mochizuki et al., 2012; Reay and Nedwell, 2004). Interestingly, this negative relationship between $\mathrm{CH}_{4}$ uptake and $\mathrm{NO}_{3}$ is the reverse of that observed across a similar transect in the Ecuadorian Andes (Wolf et al., 2012). The positive relationship between net $\mathrm{CH}_{4}$ flux and WFPS (Fig. 4d) across forest plots conforms to the expectation that highaffinity methanotrophs are limited by $\mathrm{CH}_{4}$ supply in response to diffusional constraints imposed by soil structure and water content (Curry, 2007; von Fischer et al., 2009; Smith et al., 2003). Notably, this relationship appears to be driven by decreased WFPS and increased $\mathrm{CH}_{4}$ uptake in the upper montane forest plot during the dry season. The importance of such spatial relationships between soil-atmosphere $\mathrm{CH}_{4}$ exchange and WFPS have previously been highlighted for lowland tropical soils (Verchot et al., 2000) and across the plots considered here (Teh et al., 2014) but not in studies across other montane forests, where gravimetric water contents rather than WFPS have been reported (Purbopuspito et al., 2006; Wolf et al., 2012). A positive relationship between net $\mathrm{CH}_{4}$ flux and soil temperature (Fig. 4c) was also identified. Given that we would expect metabolic rates to in- crease rather than decrease in response to increased temperature, we suggest that this relationship results from covariance between soil temperature (Table 3 ) and available $\mathrm{NO}_{3}^{-}$ or WFPS with elevation (Sousa Neto et al., 2011). Alternatively if methanogenic activity, despite limited evidence for anoxia, was playing a sizeable role in determining net $\mathrm{CH}_{4}$ flux across these forests this relationship could reflect the greater temperature sensitivity of methanogenesis relative to methanotrophy, leading to increased production at lower elevations (Segers, 1998). Similarly, in this situation the positive relationship between WFPS and net $\mathrm{CH}_{4}$ flux could reflect the promotion of anoxic microsites, not captured by our $\mathrm{O}_{2}$ measurements, by greater diffusional constraints (Verchot et al., 2000). However, we may also have expected increases in available $\mathrm{NO}_{3}^{-}$to competitively suppress methanogenic activity (Chidthaisong and Conrad, 2000). This is counter to the observation that net $\mathrm{CH}_{4}$ flux is positively correlated to available $\mathrm{NO}_{3}^{-}$and that emissions are most prevalent in the premontane forest. Greater below-ground productivity at lower elevations (Girardin et al., 2010), potentially driven by greater nutrient availability and temperature, may also stimulate $\mathrm{CH}_{4}$ production in the rhizosphere through the supply of labile substrates to methanogenic communities or maintenance of anaerobic microsites through the $\mathrm{O}_{2}$ demand of aerobic respiration (Bodelier, 2011). Such a mechanism, not observed in these data, might be supported by a positive relationship between net $\mathrm{CH}_{4}$ and $\mathrm{CO}_{2}$ fluxes (Verchot et al., 2000).

The controls on temporal variations in net $\mathrm{CH}_{4}$ flux differed among forests. As with the comparison across these forests, we found little evidence to suggest that soil $\mathrm{O}_{2}$ concentration was an important factor in determining variability in soil-atmosphere $\mathrm{CH}_{4}$ exchange. In the upper montane forest, net $\mathrm{CH}_{4}$ fluxes were best explained by a positive correlation with WFPS (Table 4), indicating that wet season increases in soil moisture act to limit the diffusion of $\mathrm{CH}_{4}$ to 

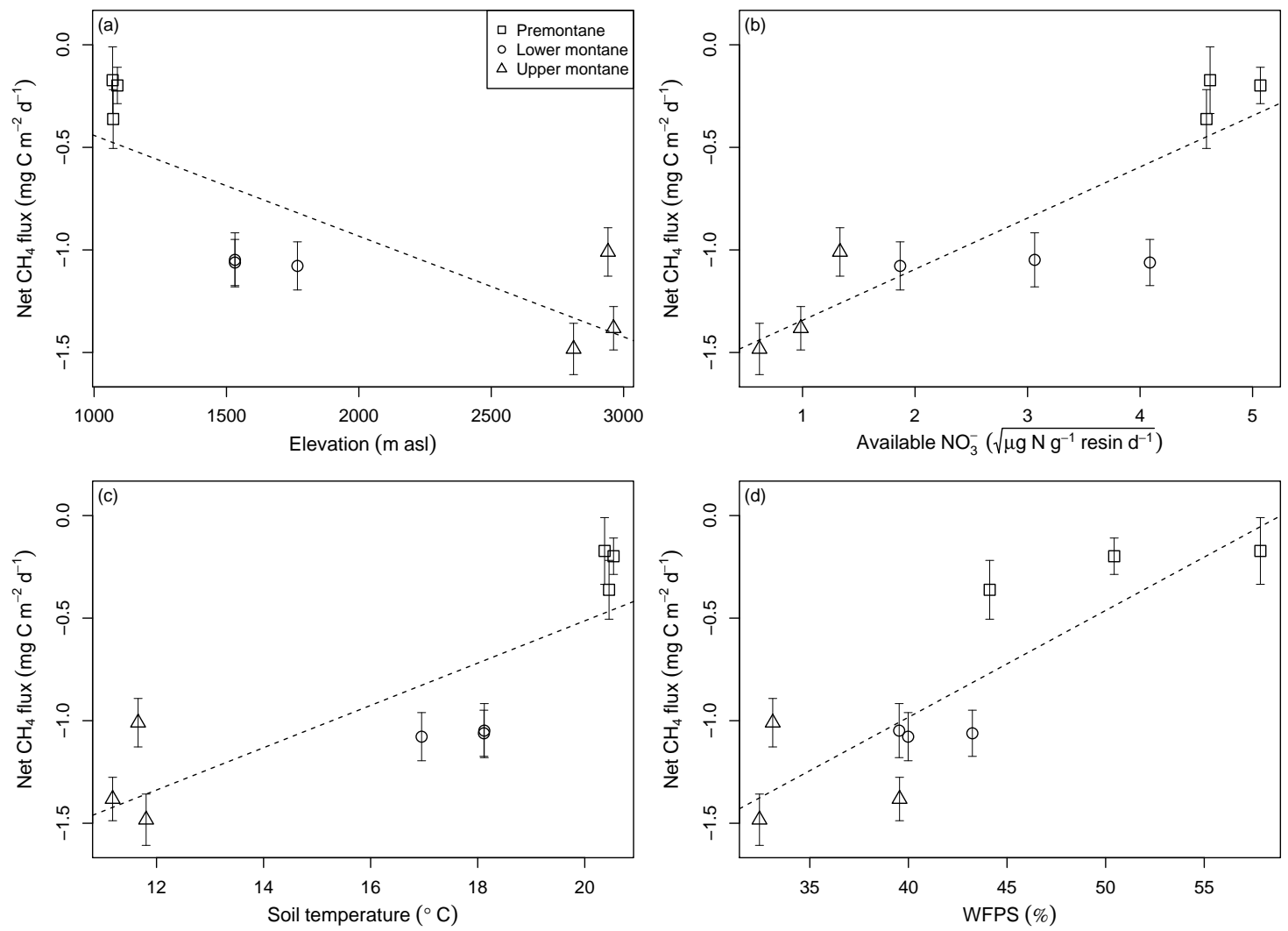

Figure 4. Relationships between dataset plot means of net $\mathrm{CH}_{4}$ flux and (a) elevation, (b) square-root transformed available $\mathrm{NO}_{3}^{-}$, (c) soil temperature and (d) WFPS across forest types. Error bars indicate standard error. Dashed lines indicate linear regression models between plot-

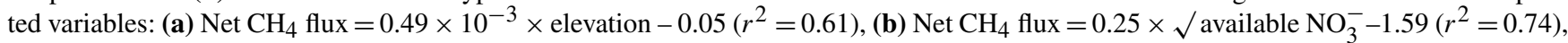
(c) $\mathrm{Net}_{\mathrm{CH}}$ flux $=0.10 \times$ soil temperature-2.58 $\left(r^{2}=0.64\right)$ and (d) $\mathrm{Net}_{\mathrm{CH}}$ flux $=0.05 \times$ WFPS-3.07 $\left(r^{2}=0.67\right)$.

methanotrophic communities. Similar to spatial relationships observed across these forests, a strong positive relationship between temporal variations in net $\mathrm{CH}_{4}$ flux and soil temperature was also observed presumably because of covariance, with wetter and warmer conditions from October to April (Fig. 1), between WFPS and soil temperature. Interestingly, the positive correlation between net $\mathrm{CO}_{2}$ flux and WFPS (Table 4) suggests that soil respiration, but not $\mathrm{CH}_{4}$ uptake, may be water limited during the dry season. Given the importance of the contribution of root and litter respiration to total soil respiration in these forests this may reflect differences in the sensitivity of the communities involved; for example, microbial communities in the litter may experience greater water limitations than those in the soil (Zimmermann et al., 2009b, 2010b). In the lower montane forest, increased $\mathrm{CH}_{4}$ uptake was related to increased $\mathrm{CO}_{2}$ flux (Table 4) indicating that conditions favourable for methanotrophy may be similar to those for general soil respiration (Purbopuspito et al., 2006; Wolf et al., 2012). Significant differences in WFPS between the wet and dry season (Table 2) were not reflected in net $\mathrm{CH}_{4}$ fluxes from these soils suggesting these variations were not great enough to sufficiently limit diffusion of $\mathrm{CH}_{4}$ as to constrain uptake rates. In the premontane forest no strong drivers of net $\mathrm{CH}_{4}$ flux were identified potentially reflecting fewer observations, the greater apparent role of production within microsites and the lack of seasonality in any of the measured parameters (Purbopuspito et al., 2006; Sousa Neto et al., 2011; Wolf et al., 2012).

\subsection{Altitudinal trends in soil $\mathrm{CH}_{4}$ cycling across tropical montane forests}

With the exception of strong source activity in some island settings, rates of $\mathrm{CH}_{4}$ uptake by tropical montane forest soils are broadly comparable across tropical montane and lowland locations globally. However the relationship between soilatmosphere $\mathrm{CH}_{4}$ exchange and elevation is poorly understood within montane regions. For example, differing patterns in soil-atmosphere $\mathrm{CH}_{4}$ exchange are reported here compared to that of altitudinal transects in Ecuador (Wolf et al., 2012) or Indonesia (Purbopuspito et al., 2006). The relationship between elevation and edaphic conditions is broadly similar for these studies (Table 5) with upper montane, lower montane and premontane forests occurring across similar 
elevation ranges (Foster, 2001). The soils of the montane forests in these three studies are differentiated from those of the premontane forests by the presence of thick organic horizons at the surface. Despite this similarity, differing relationships between net $\mathrm{CH}_{4}$ flux and elevation are apparent for the soils of Peru and Ecuador, with the former showing greatest uptake in the upper montane soils, while the latter shows greatest uptake in premontane soils (Wolf et al., 2012). Furthermore, uptake peaked in the lower montane soils in Indonesia (Purbopuspito et al., 2006). From these contrasts, it is possible to suggest that relationships with temperature identified here, as discussed with reference to spatial correlations across the Peruvian transect in the previous section, and in Ecuador (Wolf et al., 2012) result from covariance with other drivers like soil moisture or nutrient availability rather than as a result of the temperature sensitivity of $\mathrm{CH}_{4}$ uptake. Similarly, differing relationships between net $\mathrm{CH}_{4}$ fluxes and the availability of inorganic nitrogen do not allow for simple generalizations to be drawn across these ecosystems. In this study, a positive relationship between net $\mathrm{CH}_{4}$ flux and available $\mathrm{NO}_{3}^{-}$suggests inhibition of uptake, whilst a negative relationship between these parameters led Wolf (2012) to hypothesize that uptake in Ecuador was nitrogen limited. In contrast to both of these Andean studies, no relationship was identified in Indonesia (Purbopuspito et al., 2006). We speculate that the inverse altitudinal patterns in soil-atmosphere $\mathrm{CH}_{4}$ exchange in Peru and Ecuador may be driven by differences in their precipitation regimes and the influence of soil structure and water content on diffusion. Increased WFPS, a function of decreasing soil porosity and increasing precipitation across the transition from upper montane to premontane forests, appears to limit $\mathrm{CH}_{4}$ uptake in Peru through diffusional constraints on the supply of $\mathrm{CH}_{4}$ to methanotrophic communities. Whilst a similar pattern in soil porosity with elevation can be inferred from the presence of organic horizons in montane forests studied in Ecuador (Wolf et al., 2012), the alignment between increasing precipitation and decreasing $\mathrm{CH}_{4}$ uptake across this transect might suggest that diffusional constraints, in response to changes in soil moisture, might provide a generalized explanation for the patterns observed. Indeed, Veldkamp et al. (2013) invoke gas diffusional control to explain positive correlation between net annual $\mathrm{CH}_{4}$ fluxes and rainfall in a meta-analysis of seven tropical forests above $800 \mathrm{~m}$ elevation. The fact that no relationship between net $\mathrm{CH}_{4}$ flux and water content was identified in either Ecuador (Wolf et al., 2012) or Indonesia (Purbopuspito et al., 2006) may reflect the fact that both of these studies report gravimetric water content rather than WFPS, where the former moisture index does not always adequately characterize the influence of soil structure on diffusion (Verchot et al., 2000). Alternatively, given the lack of temporal correlations between $\mathrm{CH}_{4}$ exchange and soil moisture in these studies, this could also indicate that soil moisture determined at the surface poorly characterized conditions deeper in the profile where greater $\mathrm{CH}_{4}$ oxidation occurred (Purbopuspito et al.,
2006). Wolf et al. (2012) highlight that organic horizons of these montane forests are active zones of methanotrophy. It seems likely that a better understanding of the edaphic controls, relating soil structure and precipitation, on methanotrophy in such soils is required to reconcile differences in soilatmosphere $\mathrm{CH}_{4}$ exchange across such landscapes.

\section{Conclusions}

The findings of this study suggest that the upper montane, lower montane and premontane forests of south-eastern Peru principally act as sinks for atmospheric $\mathrm{CH}_{4}$. Uptake rates in these soils are comparable to activity observed globally for both montane and lowland tropical forests. Uptake rates were greatest in the upper montane forest and smallest in the premontane forest. We find that across the landscape, these soils are predominantly oxic and soil $\mathrm{CH}_{4}$ cycling is likely dominated by the activity of high affinity methanotrophs. In this regard, strong positive relationships between net $\mathrm{CH}_{4}$ flux and both available $\mathrm{NO}_{3}^{-}$and WFPS were identified suggesting that variations in $\mathrm{CH}_{4}$ uptake across the landscape may be driven by $\mathrm{NO}_{3}^{-}$inhibition and/or constraints on the diffusional ingress of $\mathrm{CH}_{4}$ from the atmosphere. Despite distinct wet and dry seasons in this region, evidence for seasonality in net $\mathrm{CH}_{4}$ fluxes were only identified in the upper montane forest soils. The increase in $\mathrm{CH}_{4}$ uptake with elevation differs with that previously reported for similar environments in Ecuador and Indonesia, suggesting that an improved understanding of the controls on methanotrophy in the organic horizons of tropical montane forest soils are required.

\section{Data Availability}

The reported datasets are available from the Centre for Environmental Data Analysis, UK Natural Environmental Research Council (Diem et al., 2016a, b, c).

\section{The Supplement related to this article is available online at doi:10.5194/bg-13-4151-2016-supplement.}

Acknowledgements. This study is a product of the Andes Biodiversity and Ecosystem Research Group consortium (http://www.andesconservation.org/). The authors would like to acknowledge the agencies that funded this research; the UK Natural Environment Research Council (NERC; joint grant references NE/G018278/1, NE/H006583, NE/H007849 and NE/H006753) and the Norwegian Agency for Development Cooperation (Norad; via a sub-contract to Yit Arn Teh managed by the Amazon Conservation Association). Patrick Meir was also supported by an Australian Research Council Fellowship (FT110100457). Javier Eduardo Silva Espejo, Walter Huaraca Huasco and the ABIDA NGO provided critical fieldwork and logistical support. Angus Calder, Michael 
Mcgibbon, Vicky Munro and Nick Morley provided invaluable laboratory support. Thanks to Adrian Tejedor and the Amazon Conservation Association (http://www.amazonconservation.org/), who provided assistance with access and plot selection at Hacienda Villa Carmen. This publication is a contribution from the Scottish Alliance for Geoscience, Environment and Society (http://www.sages.ac.uk).

Edited by: E. Veldkamp

\section{References}

Bender, M. and Conrad, R.: Kinetics of methane oxidation in oxic soils exposed to ambient air or high methane mixing ratios, FEMS Microbiol. Lett., 101, 261-269, 1992.

Bergamaschi, P., Frankenberg, C., Meirink, J. F., Krol, M., Villani, M. G., Houweling, S., Dentener, F., Dlugokencky, E. J., Miller, J. B., Gatti, L. V., Engel, A., and Levin, I.: Inverse modeling of global and regional methane emissions using SCIAMACHY satellite retrievals, J. Geophys. Res.-Atmos., 114, D22301, doi:10.1029/2009JD012287, 2009.

Bloom, A. A., Palmer, P. I., Fraser, A., Reay, D. S., and Frankenberg, C.: Large-scale controls of methanogenesis inferred from methane and gravity spaceborne data, Science, 327, 322-325, 2010.

Bodelier, P. L.: Interactions between nitrogenous fertilizers and methane cycling in wetland and upland soils, Current Opinion Environ. Sustain., 3, 379-388, 2011.

Burgin, A. J., Yang, W. H., Hamilton, S. K., and Silver, W. L.: Beyond carbon and nitrogen: how the microbial energy economy couples elemental cycles in diverse ecosystems, Front. Ecol. Environ., 9, 44-52, 2011.

Chidthaisong, A. and Conrad, R.: Turnover of glucose and acetate coupled to reduction of nitrate, ferric iron and sulfate and to methanogenesis in anoxic rice field soil, FEMS Microbiol. Ecol., 31, 73-86, 2000.

Ciais, P., Sabine, C., Bala, G., Bopp, L., Brovkin, V., Canadell, J., Chhabra, A., DeFries, R., Galloway, J., Heimann, M., Jones, C., Le Quéré, C., Myneni, R. B., Piao, S. and Thornton, P.: Carbon and Other Biogeochemical Cycles, in Climate Change 2013: The Physical Science Basis, Contribution of Working Group I to the Fifth Assessment Report of the Intergovernmental Panel on Climate Change, edited by: Stocker, T. F., Qin, D., Plattner, G.-K., Tignor, M., Allen, S. K., Boschung, J., Nauels, A., Xia, Y., Bex, V., and Midgley, P. M., 465-570, Cambridge University Press, Cambridge, United Kingdom and New York, NY, USA, available at: www.climatechange2013.org (last access: 12 December 2015), 2013.

Cicerone, R. J. and Oremland, R. S.: Biogeochemical aspects of atmospheric methane, Global Biogeochem. Cy., 2, 299-327, 1988.

Clark, K. E., Torres, M. A., West, A. J., Hilton, R. G., New, M., Horwath, A. B., Fisher, J. B., Rapp, J. M., Robles Caceres, A., and Malhi, Y.: The hydrological regime of a forested tropical Andean catchment, Hydrol. Earth Syst. Sci., 18, 5377-5397, doi:10.5194/hess-18-5377-2014, 2014.

Conrad, R.: Soil microorganisms as controllers of atmospheric trace gases (hydrogen, carbon monoxide, methane, carbonyl sulfide, nitrous oxide, and nitric oxide), Microbiol. Rev., 60, 609-640, 1996.

Curry, C. L.: Modeling the soil consumption of atmospheric methane at the global scale, Global Biogeochem. Cy., 21, GB4012, doi:10.1029/2006GB002818, 2007.

Davidson, E. A., Ishida, F. Y., and Nepstad, D. C.: Effects of an experimental drought on soil emissions of carbon dioxide, methane, nitrous oxide, and nitric oxide in a moist tropical forest, Glob. Change Biol., 10, 718-730, 2004.

Davidson, E. A., Nepstad, D. C., Ishida, F. Y., and Brando, P. M.: Effects of an experimental drought and recovery on soil emissions of carbon dioxide, methane, nitrous oxide, and nitric oxide in a moist tropical forest, Glob. Change Biol., 14, 2582-2590, 2008.

Delmas, R. A., Servant, J., Tathy, J. P., Cros, B., and Labat, M.: Sources and sinks of methane and carbon dioxide exchanges in mountain forest in equatorial Africa, J. Geophys. Res.-Atmos., 97(D6), 6169-6179, 1992.

Diem, T., Jones, S. P., Baggs, E., Smith, P., Meir, P., and Teh, Y. A.: Ground based measurements of carbon dioxide, methane and nitrous oxide taken from Villa Carmen (premontane forest) in the Peruvian Andes (2011-2013), Centre for Environmental Data Analysis, doi:10.5285/4ce0f850-2ee7-4129-9c2f68829a569348, 2016a.

Diem, T., Jones, S. P., Baggs, E., Smith, P., Meir, P., and Teh, Y. A.: Ground based measurements of carbon dioxide, methane and nitrous oxide taken from San Pedro (lower montane forest) in the Peruvian Andes (2010-2013), Centre for Environmental Data Analysis, doi:10.5285/23949dcbf101-482c-b36b-b6c2b07a4df7, 2016b.

Diem, T., Jones, S. P., Baggs, E., Smith, P., Meir, P., and Teh, Y. A.: Ground based measurements of carbon dioxide, methane and nitrous oxide taken from Wayqecha (upper montane forest) in the Peruvian Andes (2010-2013), Centre for Environmental Data Analysis, doi:10.5285/6ac947db-fc01-4ae0-ac4a-6d6ff016aad1, 2016c.

Dubinsky, E. A., Silver, W. L., and Firestone, M. K.: Tropical forest soil microbial communities couple iron and carbon biogeochemistry, Ecology, 91, 2604-2612, 2010.

Dutaur, L. and Verchot, L. V.: A global inventory of the soil methane sink, Global Biogeochem. Cy., 21, GB4013, doi:10.1029/2006GB002734, 2007.

Eva, H. D., Belward, A. S., Miranda, E. E. D., Bella, C. M. D., Gond, V., Huber, O., Jones, S., Sgrenzaroli, M., and Fritz, S.: A land cover map of South America, Glob. Change Biol., 10, 731744, 2004.

Fernandes, S. A. P., Bernoux, M., Cerri, C. C., Feigl, B. J., and Piccolo, M. C.: Seasonal variation of soil chemical properties and carbon dioxide and methane fluxes in unfertilized and $\mathrm{P}$ fertilized pastures in an Ultisol of the Brazilian Amazon, Geoderma, 107, 227-241, 2002.

Foster, P.: The potential negative impacts of global climate change on tropical montane cloud forests, Earth-Sci. Rev., 55, 73-106, 2001.

Frankenberg, C., Meirink, J. F., Weele, M. V., Platt, U., and Wagner, T.: Assessing methane emissions from global space-borne observations, Science, 308, 1010-1014, 2005.

Giblin, A. E., Laundre, J. A., Nadelhoffer, K. J., and Shaver, G. R.: Measuring Nutrient Availability in Arctic Soils Using Ion Ex- 
change Resins: A Field Test, Soil Sci. Soc. Am. J., 58, 11541162, doi:10.2136/sssaj1994.03615995005800040021x, 1994.

Girardin, C. A. J., Malhi, Y., Aragao, L., Mamani, M., Huasco, W. H., Durand, L., Feeley, K. J., Rapp, J., Silva-Espejo, J., Silman, M., and others: Net primary productivity allocation and cycling of carbon along a tropical forest elevational transect in the Peruvian Andes, Glob. Change Biol., 16, 3176-3192, 2010.

Hall, S. J., McDowell, W. H., and Silver, W. L.: When wet gets wetter: decoupling of moisture, redox biogeochemistry, and greenhouse gas fluxes in a humid tropical forest soil, Ecosystems, 16, 576-589, 2013.

Harrell, F. E. and Dupont, C.: Hmisc: Harrell Miscellaneous, available at: http://CRAN.R-project.org/package=Hmisc, last access: 27 January 2015.

Hassler, E., Corre, M. D., Tjoa, A., Damris, M., Utami, S. R., and Veldkamp, E.: Soil fertility controls soil-atmosphere carbon dioxide and methane fluxes in a tropical landscape converted from lowland forest to rubber and oil palm plantations, Biogeosciences, 12, 5831-5852, doi:10.5194/bg-12-5831-2015, 2015.

Holter, P.: Sampling air from dung pats by silicone rubber diffusion chambers, Soil Biol. Biochem., 22, 995-997, 1990.

Hothorn, T., Bretz, F., and Westfall, P.: Simultaneous Inference in General Parametric Models, Biometrical J., 50, 346-363, 2008.

Hutchinson, G. L. and Mosier, A. R.: Improved Soil Cover Method for Field Measurement of Nitrous Oxide Fluxes, Soil Sci. Soc. Am. J., 45, 311-316, doi:10.2136/sssaj1981.03615995004500020017x, 1981.

Ishizuka, S., Iswandi, A., Nakajima, Y., Yonemura, S., Sudo, S., Tsuruta, H., and Muriyarso, D.: Spatial patterns of greenhouse gas emission in a tropical rainforest in Indonesia, Nutr. Cycl. Agroecosys., 71, 55-62, 2005a.

Ishizuka, S., Iswandi, A., Nakajima, Y., Yonemura, S., Sudo, S., Tsuruta, H., and Murdiyarso, D.: The variation of greenhouse gas emissions from soils of various land-use/cover types in Jambi province, Indonesia, Nutr. Cycl. Agroecosys., 71, 17-32, $2005 \mathrm{~b}$.

Jacinthe, P. A. and Dick, W. A.: Use of silicone tubing to sample nitrous oxide in the soil atmosphere, Soil Biol. Biochem., 28, 721-726, 1996

Kammann, C., Grünhage, L. and Jäger, H. J.: A new sampling technique to monitor concentrations of methane, nitrous oxide and carbon dioxide in air at well-defined depths in soils with varied water potential, Eur. J. Soil Sci., 52, 297-303, 2001.

Keller, M., Kaplan, W. A., and Wofsy, S. C.: Emissions of nitrous oxide, methane and carbon dioxide from tropical forest soils, J. Geophys. Res.-Atmos., 91, 11791-11802, 1986.

Keller, M., Varner, R., Dias, J. D., Silva, H., Crill, P., Asner, G. P., and others: Soil-Atmosphere Exchange of Nitrous Oxide, Nitric Oxide, Methane, and Carbon Dioxide in Logged and Undisturbed Forest in the Tapajos National Forest, Brazil, Earth Interact., 9, 1-21, 2005.

Kiese, R., Wochele, S., and Butterbach-Bahl, K.: Site specific and regional estimates of methane uptake by tropical rainforest soils in north eastern Australia, Plant Soil, 309, 211-226, 2008.

Klute, A. (Ed.): Methods of soil analysis, Part 1. Physical and mineralogical methods, American Society of Agronomy, Inc., 1986.

Le Mer, J. and Roger, P.: Production, oxidation, emission and consumption of methane by soils: a review, Eur. J. Soil Biol., 37, 25-50, 2001.
Liptzin, D., Silver, W. L., and Detto, M.: Temporal dynamics in soil oxygen and greenhouse gases in two humid tropical forests, Ecosystems, 14, 171-182, 2011.

Livingston, G. and Hutchinston, G.: Chapter 2: Enclosure-based measurement of trace gas exchange: applications and sources of error, in: Biogenic Trace Gases: Measuring Emissions from Soil and Water, edited by: Matson, P. and Harriss, R. C., Blackwell Scientific Ltd., 1995.

Malhi, Y., Silman, M., Salinas, N., Bush, M., Meir, P., and Saatchi, S.: Introduction: elevation gradients in the tropics: laboratories for ecosystem ecology and global change research, Glob. Change Biol., 16, 3171-3175, 2010.

Mochizuki, Y., Koba, K., and Yoh, M.: Strong inhibitory effect of nitrate on atmospheric methane oxidation in forest soils, Soil Biol. Biochem., 50, 164-166, 2012.

Myhre, G., Shindell, D., Bréon, F. M., Collins, W., Fuglestvedt, J., Huang, J., Koch, D., Lamarque, J. F., Lee, D., Mendoza, B., Nakajima, T., Robock, A., Stephens, G., Takemura, T., and Zhang, H.: Anthropogenic and Natural Radiative Forcing, in: Climate Change 2013: The Physical Science Basis, Contribution of Working Group I to the Fifth Assessment Report of the Intergovernmental Panel on Climate Change, edited by: Stocker, T. F., Qin, D., Plattner, G.-K., Tignor, M., Allen, S. K., Boschung, J., Nauels, A., Xia, Y., Bex, V., and Midgley, P. M., 659-740, Cambridge University Press, Cambridge, United Kingdom and New York, NY, USA, available at: www.climatechange2013.org (last access: 12 December 2015),2013.

Nottingham, A. T., Ccahuana, A. J., and Meir, P.: Soil properties in tropical montane cloud forests influence estimates of soil carbon dioxide efflux, Agr. Forest Meteorol., 166, 215-220, 2012.

Pedersen, A. R.: HMR: Flux estimation with static chamber data, available at: http://cran.r-project.org/package=HMR (last access: 28 February 2015), 2012.

Pedersen, A. R., Petersen, S. O., and Schelde, K.: A comprehensive approach to soil-atmosphere trace-gas flux estimation with static chambers, Eur. J. Soil Sci., 61, 888-902, 2010.

Pinheiro, J., Bates, D., DebRoy, S., Sarkar, D., and R Core Team: nlme: Linear and Nonlinear Mixed Effects Models, available at: http://CRAN.R-project.org/package=nlme (last access: 3 April 2015), 2014.

Pinheiro, J. C. and Bates, D. M.: Mixed-effects models in S and S-PLUS, Springer, 2000.

Pumpanen, J., Kolari, P., Ilvesniemi, H., Minkkinen, K., Vesala, T., Niinistö, S., Lohila, A., Larmola, T., Morero, M., Pihlatie, M., and others: Comparison of different chamber techniques for measuring soil carbon dioxide efflux, Agr. Forest Meteorol., 123, 159-176, 2004.

Purbopuspito, J., Veldkamp, E., Brumme, R., and Murdiyarso, D.: Trace gas fluxes and nitrogen cycling along an elevation sequence of tropical montane forests in Central Sulawesi, Indonesia, Global Biogeochem. Cy., 20, GB3010, doi:10.1029/2005GB002516, 2006.

R Core Team: R: A Language and Environment for Statistical Computing, R Foundation for Statistical Computing, Vienna, Austria, available at: http://www.r-project.org (last access: 3 April 2015), 2013.

Reay, D. S. and Nedwell, D. B.: Methane oxidation in temperate soils: effects of inorganic N, Soil Biol. Biochem., 36, 2059-2065, 2004. 
Schuur, E. A., Chadwick, O. A., and Matson, P. A.: Carbon cycling and soil carbon storage in mesic to wet Hawaiian montane forests, Ecology, 82, 3182-3196, 2001.

Segers, R.: Methane production and methane consumption: a review of processes underlying wetland methane fluxes, Biogeochemistry, 41, 23-51, 1998.

Sexstone, A. J., Revsbech, N. P., Parkin, T. B., and Tiedje, J. M.: Direct measurement of oxygen profiles and denitrification rates in soil aggregates, Soil Sci. Soc. Am. J., 49, 645-651, 1985.

Silver, W. L., Lugo, A. E., and Keller, M.: Soil oxygen availability and biogeochemistry along rainfall and topographic gradients in upland wet tropical forest soils, Biogeochemistry, 44, 301-328, 1999.

Smith, K. A., Ball, T., Conen, F., Dobbie, K. E., Massheder, J., and Rey, A.: Exchange of greenhouse gases between soil and atmosphere: interactions of soil physical factors and biological processes, Eur. J. Soil Sci., 54, 779-791, 2003.

Sousa Neto, E., Carmo, J. B., Keller, M., Martins, S. C., Alves, L. F., Vieira, S. A., Piccolo, M. C., Camargo, P., Couto, H. T. Z., Joly, C. A., and Martinelli, L. A.: Soil-atmosphere exchange of nitrous oxide, methane and carbon dioxide in a gradient of elevation in the coastal Brazilian Atlantic forest, Biogeosciences, 8, 733-742, doi:10.5194/bg-8-733-2011, 2011.

Spahni, R., Wania, R., Neef, L., van Weele, M., Pison, I., Bousquet, P., Frankenberg, C., Foster, P. N., Joos, F., Prentice, I. C., and van Velthoven, P.: Constraining global methane emissions and uptake by ecosystems, Biogeosciences, 8, 1643-1665, doi:10.5194/bg8-1643-2011, 2011.

Steudler, P. A., Bowden, R. D., Melillo, J. M., and Aber, J. D.: Influence of nitrogen fertilization on methane uptake in temperate forest soils, Nature, 341, 314-316, doi:10.1038/341314a0, 1989.

Steudler, P. A., Melillo, J. M., Feigl, B. J., Neill, C., Piccolo, M. C., and Cerri, C. C.: Consequence of forest-to-pasture conversion on methane fluxes in the Brazilian Amazon Basin, J. Geophys. Res.Atmos., 101, 18547-18554, 1996.

Teh, Y. A., Silver, W. L., and Conrad, M. E.: Oxygen effects on methane production and oxidation in humid tropical forest soils, Glob. Change Biol., 11, 1283-1297, 2005.

Teh, Y. A., Silver, W. L., Conrad, M. E., Borglin, S. E., and Carlson, C. M.: Carbon isotope fractionation by methane-oxidizing bacteria in tropical rain forest soils, J. Geophys. Res.-Biogeo., 111, G02001, doi:10.1029/2005JG000053, 2006.

Teh, Y. A., Dubinsky, E. A., Silver, W. L., and Carlson, C. M.: Suppression of methanogenesis by dissimilatory iron (III)-reducing bacteria in tropical rain forest soils: Implications for ecosystem methane flux, Glob. Change Biol., 14, 413-422, 2008.

Teh, Y. A., Diem, T., Jones, S., Huaraca Quispe, L. P., Baggs, E., Morley, N., Richards, M., Smith, P., and Meir, P.: Methane and nitrous oxide fluxes across an elevation gradient in the tropical Peruvian Andes, Biogeosciences, 11, 2325-2339, doi:10.5194/bg-11-2325-2014, 2014.

Templer, P., Lovett, G., Weathers, K., Findlay, S., and Dawson, T. E.: Influence of Tree Species on Forest Nitrogen Retention in the Catskill Mountains, New York, USA, Ecosystems, 8, 1-16, doi:10.1007/s10021-004-0230-8, 2005.

Tovar, C., Arnillas, C. A., Cuesta, F., and Buytaert, W.: Diverging responses of tropical Andean biomes under future climate conditions, PloS One, 8, e63634, doi:10.1371/journal.pone.0063634, 2013.
Varner, R. K., Keller, M., Robertson, J. R., Dias, J. D., Silva, H., Crill, P. M., McGroddy, M., and Silver, W. L.: Experimentally induced root mortality increased nitrous oxide emission from tropical forest soils, Geophys. Res.Lett., 30, 1-4, doi:10.1029/2002GL016164, 2003.

Veldkamp, E., Koehler, B., and Corre, M. D.: Indications of nitrogen-limited methane uptake in tropical forest soils, Biogeosciences, 10, 5367-5379, doi:10.5194/bg-10-5367-2013, 2013.

Verchot, L. V., Davidson, E. A., Cattânio, J. H., and Ackerman, I. L.: Land-use change and biogeochemical controls of methane fluxes in soils of eastern Amazonia, Ecosystems, 3, 41-56, 2000.

von Fischer, J. C. and Hedin, L. O.: Controls on soil methane fluxes: Tests of biophysical mechanisms using stable isotope tracers, Global Biogeochem. Cy., 21, GB2007, doi:10.1029/2006GB002687, 2007.

von Fischer, J. C., Butters, G., Duchateau, P. C., Thelwell, R. J., and Siller, R.: In situ measures of methanotroph activity in upland soils: A reaction-diffusion model and field observation of water stress, J. Geophys. Res.-Biogeo., 114 doi:10.1029/2008JG000731, 2009.

Werner, C., Zheng, X., Tang, J., Xie, B., Liu, C., Kiese, R., and Butterbach-Bahl, K.: Nitrous oxide, methane and carbon dioxide emissions from seasonal tropical rainforests and a rubber plantation in Southwest China, Plant Soil, 289, 335-353, 2006.

Werner, C., Kiese, R., and Butterbach-Bahl, K.: Soil-atmosphere exchange of $\mathrm{N}_{2} \mathrm{O}, \mathrm{CH}_{4}$, and $\mathrm{CO}_{2}$ and controlling environmental factors for tropical rain forest sites in western Kenya, J. Geophys. Res.-Atmos., 112, D03308, doi:10.1029/2006JD007388, 2007.

Wolf, K., Flessa, H., and Veldkamp, E.: Atmospheric methane uptake by tropical montane forest soils and the contribution of organic layers, Biogeochemistry, 111, 469-483, 2012.

Zimmermann, M., Meir, P., Bird, M. I., Malhi, Y., and Ccahuana, A. J. Q.: Climate dependence of heterotrophic soil respiration from a soil-translocation experiment along a $3000 \mathrm{~m}$ tropical forest altitudinal gradient, Eur. J. Soil Sci., 60, 895-906, 2009a.

Zimmermann, M., Meir, P., Bird, M., Malhi, Y., and Ccahuana, A.: Litter contribution to diurnal and annual soil respiration in a tropical montane cloud forest, Soil Biol. Biochem., 41, 1338-1340, doi:10.1016/j.soilbio.2009.02.023, 2009b.

Zimmermann, M., Meir, P., Silman, M. R., Fedders, A., Gibbon, A., Malhi, Y., Urrego, D. H., Bush, M. B., Feeley, K. J., Garcia, K. C., Dargie, G. C., Farfan, W. R., Goetz, B. P., Johnson, W. T., Kline, K. M., Modi, A. T., Rurau, N. M. Q., Staudt, B. T., and Zamora, F.: No differences in soil carbon stocks across the tree line in the Peruvian Andes, Ecosystems, 13, 62-74, 2010a.

Zimmermann, M., Meir, P., Bird, M. I., Malhi, Y., and Ccahuana, A. J.: Temporal variation and climate dependence of soil respiration and its components along a $3000 \mathrm{~m}$ altitudinal tropical forest gradient, Global Biogeochem. Cy., 24, GB4012, doi:10.1029/2010GB003787, 2010b.

Zuur, A. F., Ieno, E. N., and Smith, G. M.: Analysing ecological data, Springer, New York, 2007. 